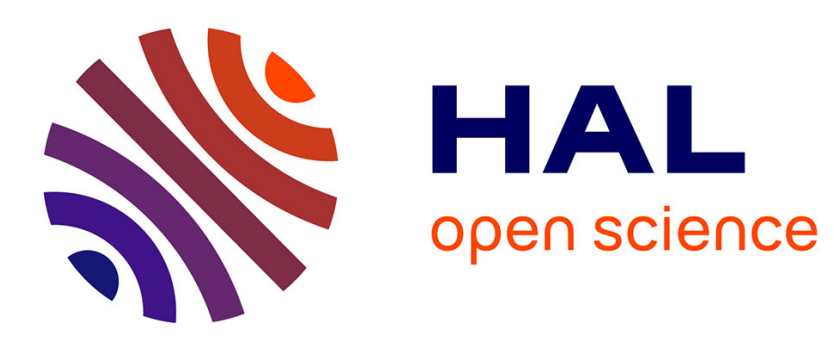

\title{
Industrial activities and primary schooling in early nineteenth-century France
}

Adrien Montalbo

\section{To cite this version:}

Adrien Montalbo. Industrial activities and primary schooling in early nineteenth-century France. 2018. halshs-01826346v2

\section{HAL Id: halshs-01826346 \\ https://shs.hal.science/halshs-01826346v2}

Preprint submitted on 16 Jan 2019

HAL is a multi-disciplinary open access archive for the deposit and dissemination of scientific research documents, whether they are published or not. The documents may come from teaching and research institutions in France or abroad, or from public or private research centers.
L'archive ouverte pluridisciplinaire HAL, est destinée au dépôt et à la diffusion de documents scientifiques de niveau recherche, publiés ou non, émanant des établissements d'enseignement et de recherche français ou étrangers, des laboratoires publics ou privés. 


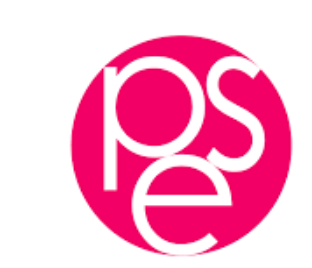

PARISSCHOOL OFECONOMICS
ECOLED'ECONOMIEDEPARIS

WORKING PAPER Nº $2018-33$

\title{
Industrial activities and primary schooling in early nineteenth-century France
}

\author{
Adrien Montalbo
}

JEL Codes: N33, N63

Keywords : primary instruction, industrial activities, nineteenth-century France
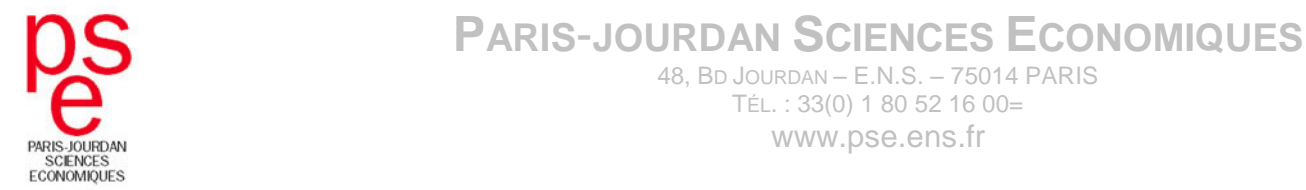


\title{
Industrial activities and primary schooling in early nineteenth-century France
}

\author{
Adrien Montalbo*†
}

November 30, 2018

\begin{abstract}
This article investigates the impact of industrial activities on primary instruction in early nineteenth-century France. To do so, I use a newly constituted database on the location and characteristics of primary schools at the level of municipalities. This database is extracted from the Guizot Survey conducted in 1833, before the implementation of the first national law making the opening of a school mandatory in any municipality more than 500 inhabitants. By using mineral deposits as an instrument, I first show that the presence of industrial activities in a given municipality was positively influencing the presence of primary schools. An increase in the supply of schools by municipalities explains this association. Additional resources transferred to them by manufactures favoured this increase trough an income effect. However, I find no significant link between industry and the accumulation of human capital. On the contrary, I provide indications that industrial activities were associated with lower enrolment rates. If they had a positive impact on the demand for schooling, it was only for a very restricted part of the population.
\end{abstract}

JEL codes : N33, N63

Keywords : primary instruction, industrial activities, nineteenth-century France

*Paris School of Economics, montalboadrien@gmail.com, 0782860449. Montalbo Adrien, Lieu dit Montermont, 73460 Notre Dame des Millières. Declarations of interest: none.

${ }^{\dagger}$ I am grateful to Jerôme Bourdieu, Lionel Kesztenbaum, Eric Maurin and Quentin Lippman for helpful comments. I would like to thank Anne-Marie Chartier and André Oliva for helping me access the archives and sharing data on the Guizot Survey. I am also grateful to participants at the seminars in the Paris School of Economics, 67th Annual Meeting of the French Economic Association and 35èmes Journées de Microéconomie Appliquée. 


\section{Introduction}

In economic history, the impact of industrialisation on education has been greatly debated. It has been argued, in the British case for example, that early industrialisation and the progressive introduction of large-scale factories using steam-power were mainly skill-saving. They favoured the development of low-skilled jobs and the fall in semi-skilled blue-collar jobs such as weavers, shoemakers or tailors (de Pleijt and Weisdorf, 2014), possibly diminishing the demand for instruction and literacy rate in England (de Pleijt, 2018). This came under the name of the "deskilling hypothesis" (Sanderson, 1972), (Nicholas and Nicholas, 1992). The same observation has been made on the level and growth of secondary instruction in the United States (Goldin and Katz, 1997). This negative effect of industrial activities on literacy rates was also identified in the French case. In the Nord department, for example, industrial districts were found to be characterised by relatively low literacy rates between 1831 and 1843 (Leblond, 1970). By the same token, the presence of a developed textile sector was correlated with a lower literacy in the diocese of Rouen at the end of the $18^{\text {th }}$ century (Furet and Ozouf, 1977b).

However, industrialisation and technical changes may also have led to a rise in the demand for some medium and high-skilled workers (Feldman and van der Beek, 2015), (de Pleijt et al., 2016), especially during its second phase (Mokyr, 2008) ${ }^{1}$. Moreover, in the English or French cases, it is not obvious to show that industrialisation was the very cause of a fall in literacy rate (Schofield, 1973), (Corbin, 1975), all the more since a sharp increase in this rate took place at the beginning of the nineteenth century, precisely at the time when industrial activities surged (Laqueur, 1974). Controlling by Irish immigration also diminishes the scope of the argument in the British case (West, 1978). Therefore, the higher demand for low-skill workers, caused by the industry, may not have affected greatly literacy as it wasn't inducing people previously sending their children to school to stop doing so.

In the case of France, there seems to have been a complementarity between technology and human capital. Franck and Galor, 2017, found that the number of steam engines at the department level in 1839-1847 influenced strongly human capital accumulation in the early phase of industrialisation. A larger number of steam engines had a significant impact on the number of teachers later in the century, on the share of apprentices in the population, on the share of literate conscripts, on the number of schoolhouses and on the number of pupils enrolled in primary schools relative to the number of inhabitants. Similarly, Diebolt et al., 2017a found that the number of steam engines within departments was positively associated with literacy rates and primary schools' presence in the first part of the nineteenth century. The association became non-significant after 1850 and a positive relation emerged with adult education and superior primary schools, the level of education subsequent to primary schooling strictly speaking $^{2}$. More generally, the positive influence of industry may have been due to an income effect on the supply and demand for schooling, to a higher demand for skills within the factories, or to the will of manufacturers to enhance discipline within the workforce.

\footnotetext{
${ }^{1}$ See (Katz, 2016) for an illustration in the American context.

${ }^{2}$ This level corresponds to what is called "secondary education" nowadays.
} 
In this article, I adopt a more micro-historical approach in order to evaluate how industrial activities influenced primary schooling in early nineteenth-century France, at the beginning of French industrial era. I do so by testing the effect of the presence of industrial factories on the supply and demand of primary schooling at the level of municipalities. I focus on manufactures more than ten workers and not on proto-industrial activities. This level of disaggregation will help to understand in concrete terms the relationship between the two phenomena and its transmission channels. I use a newly constituted database on education at the level of municipalities in this work. This database is extracted from a national survey launched by French Minister of Education François Guizot in 1833. The survey, conducted in every primary school of every French municipality, provides very precise information on the characteristics of schools, teachers and municipal investment in education. I collected the data at the municipal level for 22 departments, which amounts to 8129 towns and villages, a primary school being located in $59.5 \%$ of them.

I test the influence of industrial activities on primary schooling first by using a simple OLS framework. Indeed, the onset of industrialisation in France was linked to upper-tailed knowledge influencing positively the adoption of modern technology, this knowledge being uncorrelated with basic indicators of literacy (Squicciarini and Voigtländer, 2015). Therefore, even if the issue of reverse causality cannot be utterly ruled out, it doesn't constitute the major concern about the validity of least squares estimators. More worryingly, a third factor like wealth coming from trade or agriculture may have influenced both the presence of schools and factories. Therefore, to deal with this potential omitted variable bias, I use data on the location of ore to instrument the presence of industrial manufactures. This location was linked to mining activities which depended by definition directly on mineral deposits. Moreover, these activities could have also attracted other industrial sectors, as the production of metal objects and tools or the production of clothes, interested in benefiting from the outlet constituted by the presence of mines.

First, I show that the presence of industrial manufactures influenced positively and significantly the location of primary schools, both in the OLS and the IV estimations. This effect was, as expected, greatly due to mining activities when using the instrumental variable technique. It was also greater in magnitude for larger manufactures, namely those more than 20 workers. An increase in the supply of primary schools by municipalities accounted for this association. Industrial activities, trough taxes applied on their production, contributed to increase the economic resources of municipalities. This enabled them to invest more intensively in primary schooling.

Before the Guizot Law, municipalities had no legal obligation to invest in primary instruction. Schools could be totally funded through fees (known as the écolage) paid by parents, partly by the fees and municipal grants and solely by municipalities ${ }^{3}$. The school was said to be private in the first case, public in the last two of them. Paying teachers on a fixed annual basis and providing them with a classroom or an accommodation were the three main types of municipal

\footnotetext{
${ }^{3}$ This last case in which parents could benefit freely from a schooling service was extremely rare at the beginning of the nineteenth century.
} 
grants. The impact of industrial activities on the supply of school was therefore due to an increase in the provision of public primary schools.

Indeed, I provide indications that these activities were not associated with a higher demand for schooling and accumulation of human capital. Enrolment rates were on average lower in municipalities with factories, especially if these factories belonged to sectors whose workforce was constituted by a large share of children. I also find a positive correlation between the presence of industry and the number of subjects taught within schools. However, even if manufactures prompted this extension of education, it remained restricted to a very limited number of pupils. Therefore, industrialisation, in its initial phase, had either no or a negative impact on the extensive margin of human capital accumulation, and only at best a slightly positive effect on its intensive margin.

This analysis adds to the debate about the influence of early industrialisation on education in two ways. First, it focuses on France, a country much less studied than England from that perspective. Second, thanks to data collected at the municipal level and to the use of deposits as an instrument, I can estimate the causal impact of industrial activities on schooling. This impact was positive for what regards the supply of (public) schools, but flat or negative on the demand for schooling.

The next section presents some historical facts about primary schooling and industrial activities from the Revolution to the Guizot Law of 1833 and helps to contextualise and to specify the study. Section 3 is a description of the data I use while Section 4 presents the research methodology adopted. Econometric results are presented in Section 5 for what regards the presence of primary schools and transmission channels are studied in Section 6. In Section 7, the influence of industrial activities on human capital accumulation is presented. Section 8 concludes.

\section{A Differentiated Development of Primary Schooling and Industrial Activities}

The Guizot Law was passed on the 28th of June 1833, making compulsory for any municipality over 500 inhabitants to open and maintain a primary school for boys. Teachers were also to be paid on a regular basis, not less than 200 francs a year. This law was the first major step towards universal schooling undertaken in France. To this date, the decision to open a primary school (along with paying the teacher on a fixed basis or not, how much, buying books, blackboards and other pieces of furniture, providing the teacher with an accommodation or a classroom,...) was mainly made at the level of municipalities ${ }^{4}$. Local authorities thus played an important role, along with parents who were in most cases (except when they were listed as

\footnotetext{
${ }^{4} \mathrm{~A}$ precise description of the daily life of schools and teachers in the eighteenth and early nineteenth centuries can be found in (Duveau, 1957). Analyses or testimonies on the state of primary schooling by teachers from the early nineteenth century are available in (Lorain, 1837) and (Meunier, 1981). In order to have an analysis of local schooling development in the eighteenth century, see for example (Vovelle, 1975) or (Laget, 1971). See (Gildea, 1983) for a local study from 1800 onwards for the departments of Ille-et-Vilaine, Gard and Nord.
} 
indigents by the municipality or when the school was totally free, which was extremely rare at that time) paying fees so that their children could attend school.

At the state level, many reforms took place during the French Revolution to legislate on primary schooling ${ }^{5}$. The major orientations of the reforms were to separate instruction from religious influences, to create a distinct teaching for boys and for girls and to grant people with free and universal education. However, the effect of the revolutionary period on education remained small, mainly due to a lack of financial means and to the difficulty to legislate in an unstable political context (Mayeur, 2004). This evolved under the Restoration. From the 29th of February 1816, a written certification of morality was mandatory in order to teach, this certification being delivered by the mayor and the parish priest. The capacities of teachers were also to be checked by a civil servant. A certificate composed of three different degrees, the third one being the lowest on the hierarchy, was from then on a prerequisite for teaching. However, this was also rarely fully applied ${ }^{6}$. Indeed, examinations often took place after the nomination of teachers. If they were unable to pass the tests, authorities should have refused them the certificate and close the school, a measure which was unlikely to be implemented (Prost, 1968). In this context, primary schooling developed differentially across regions. From the early work of the Dupin baron, an opposition has been drawn between a well-educated France above the Saint-Malo/Geneva line and a less-educated one below (Dupin, 1826) ${ }^{7}$. For example, in the 1820s, the enrolment per 100 children six to thirteen years of age was higher north of the line, with a mean of 94, compared to south of it, with an average level of 53. This was also true for the schooling of girls (Grew and Harrigan, 1991). Figure 1 depicts this distinction between French departments. Controlling by the age structure doesn't change much the results ${ }^{8}$. Therefore, before the Guizot Law, primary schools and high enrolment rates were mostly concentrated in the north-east part of France, even if some other regions as the Rhône Valley and the Gironde were also characterised by rather good schooling levels.

\footnotetext{
${ }^{5}$ In order to have a full political analysis and a description of the laws, projects, and debates about primary instruction during this period of time, one can refer to (Gontard, 1959) and the second and third chapters in (Furet and Ozouf, 1977a).

${ }^{6}$ See (Nique, 1990) to have a description of educational state measures from 1815 onwards.

${ }^{7}$ This analysis has been partly contested as it didn't take into account the age structure of the population (Fleury and Valmary, 1957).

${ }^{8}$ This is done in Figure B1 in the Appendix.
} 


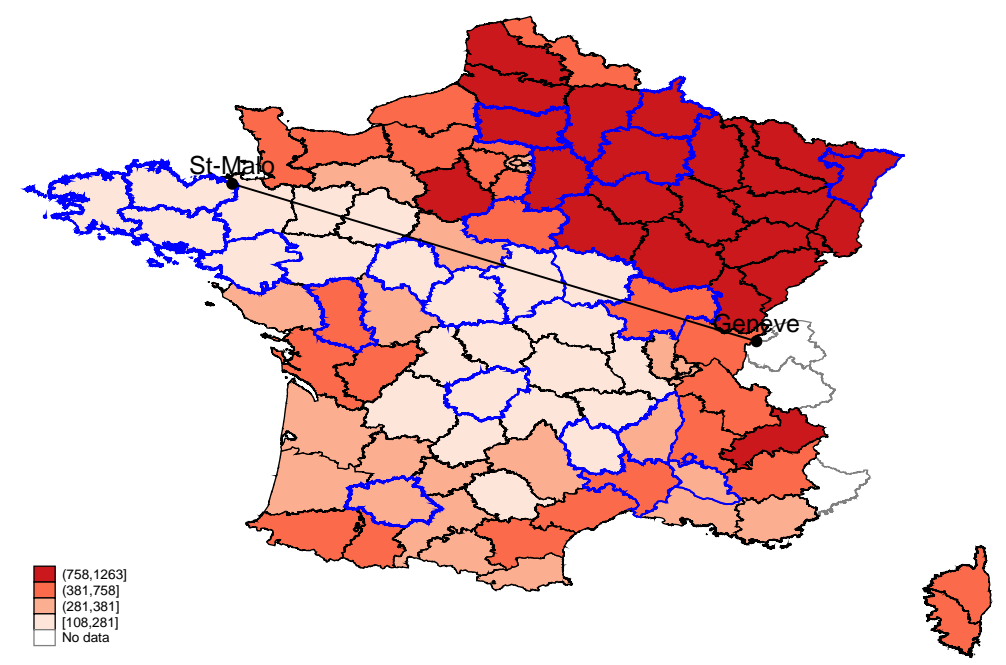

Figure 1: Number of pupils attending primary schools - winter 1833 (over 10000 inhabitants)

Source: Statistique générale de la France, Guizot survey - Report to the King.

Note: Departments in blue are the ones for which education data are available at the level of municipalities.

As reported in Figure 2, the spread and geographical distribution of industrial activities in 1839-1847 differed from the one of primary schooling. Manufactures were mostly concentrated in the north-west and western departments close to the Atlantic Ocean. This concentration was associated to the volume of commercial activities in Atlantic ports like Le Havre, La Rochelle or Nantes (Asselain, 1984). Manufactures more than 20 workers (along with the number of steam engines and the number of industrial workers) were more concentrated in the north and north-eastern parts of France, along with the Rhône Valley. This was associated to the progressive surge of mining and metallurgic sectors in France at that time, in particular to the exploitation of coal and iron. Deposits were indeed highly concentrated in the Nord-Pas-deCalais, Lorraine, Auvergne, Loire, Dauphiné, Provence and Cévennes areas in France. In some regions as Normandie or the Dauphiné, the concomitant presence of rivers, forests and deposits explains the ancient presence of metallurgic sectors (Léon, 1948), (Richard, 1962), (Kellenbenz, 1963). Textile activities also followed closely this geographical pattern (Dunham, 1953).

The early nineteenth century is the time period of the first industrialisation in France. Food industry and textile were the leading sectors. Each of them accounted for one-third of the total industrial product, steel industry for one-tenth. Industrial production growth rates began to surge at that time, being superior to $3 \%$ for the best years from 1815 onwards (Lévy-Leboyer, 1968). The highest rates were attained at the end of the July Monarchy and under the Second Empire (Crouzet, 1970). This growth remained however quite gradual all over the century, which led some authors to deny the idea of a real industrial take-off in France (Mendels, 1972) ${ }^{9}$.

\footnotetext{
${ }^{9}$ To have an economic analysis and description of the industrialisation period in France and other European countries over the nineteenth century, see (Verley, 1999) and (Verley, 1997). For an analysis of the French case under the Ancien Régime, see for example (Sée, 1925).
} 


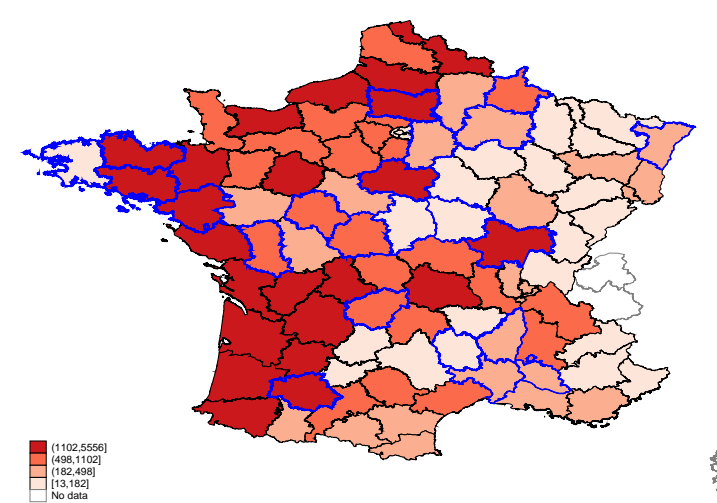

(a) Number of manufactures

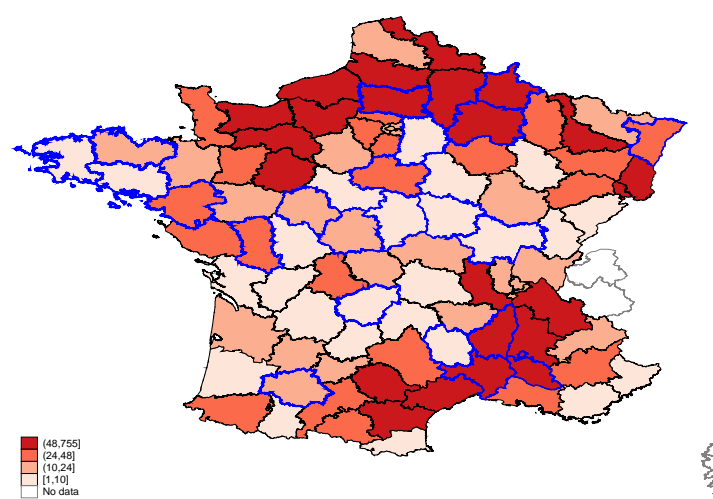

(c) Number of textile factories

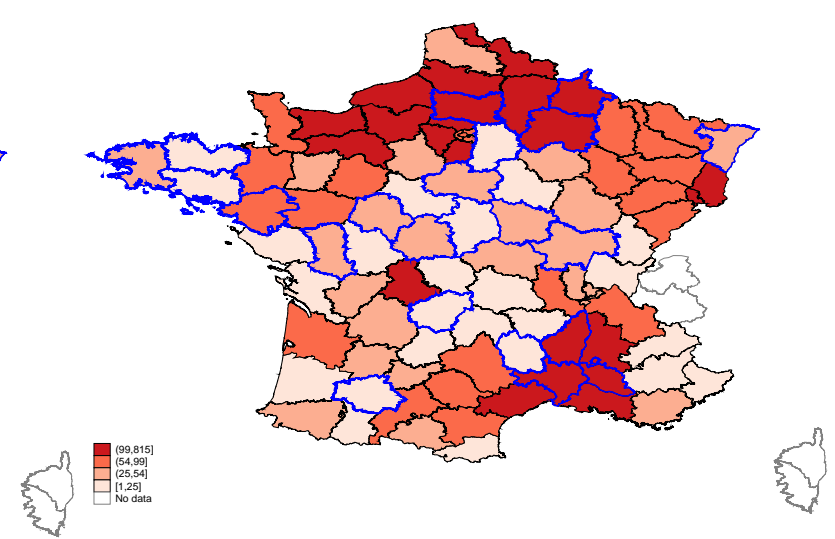

(b) Number of manufactures more than 20 workers

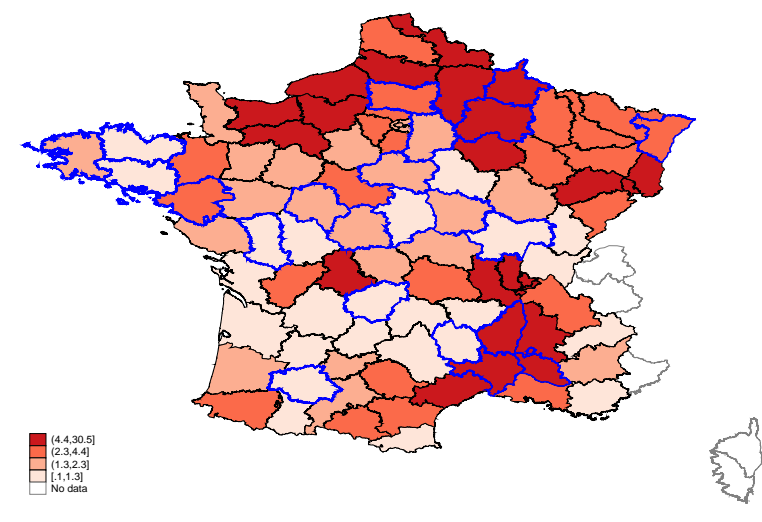

(d) Industrial child workers per 1000 inhabitants

Figure 2: Industrial activities in France, 1839-1847

Source: Industrial survey.

Note: Departments in blue are the ones for which education data are available at the level of municipalities.

\section{Data}

\subsection{Data on Education}

In 1833, when the Guizot Law was passed, a survey at the national level was conducted in order to evaluate the state of primary schooling in France, under the supervision of Guizot ${ }^{10}$. 490 inspectors were sent throughout France in autumn 1833. All primary schools, both public and private, were to be examined. However, primary schools to which only girls were attending were excluded from the scope of the survey as the Guizot law didn't apply to them. All departments were inspected, except Corsica.

Data coming from the Guizot Survey of 1833 was published for all French districts in a Report to the King (Guizot, 1834). These districts (arrondissements départementaux or sous-préfectures) correspond to an administrative subdivision of departments (counties). Two to six of them existed in each department. Only some of the questions asked in the initial survey, those deemed

\footnotetext{
${ }^{10} \mathrm{~A}$ lot of information on this survey is available here : http://www.inrp.fr/she/guizot/.
} 
of major interest, were aggregated in this report. From the initial individual (at the level of each primary school) forms, the data was collected for 22 departments and 8129 municipalities ${ }^{11}$. At least one primary school was present in 4836 of them (59.5\%). This project has been initiated by the Service d'Histoire de l'Education of the I.N.R.P, which collected data for the academies of Nantes, Bourges and Nîmes. Other departments were then added to this initial database. In Figure 1, one can see that these departments (in blue) belong to areas with very different levels of enrolment. Collection of data was indeed conducted with the aim of catching all the determinants that underpinned primary schools spreading. This, added to the focus at the municipal level, should helps avoiding some of the criticisms that were pronounced against the reliance of aggregated historical data on primary schools ${ }^{12}$. Other data on education is coming from the Statistique générale de la France ${ }^{13}$.

The departments selected are quite representative of France for what regards primary education and the industrial characteristics which will be under scrutiny in this analysis. Taking average values at the level of districts in order to compare this "municipal level sample" to the entire country thanks to the Report to the King ${ }^{14}$ shows that the sample differs significantly only in the percentage of municipalities with factories (21.6\% against $17.2 \%$ for France) when considering industrial factors. The number of workers, their average wages, the amount of industrial production or the presence of large factories (more than 20 workers, the top one-third in terms of size) didn't differ significantly between them. The same is true for the investment of municipalities in primary education (provision of a fixed salary or an accommodation to teachers) and for the number of primary schools. However, enrolment rates and the percentage of municipalities with schools (60.8\% against $71.5 \%$ for France) are lower in the sample, which means that the departments at stake were less well-endowed in primary schools than at the national level. This is why several agricultural wealth controls, district and department fixed effects will be introduced in the estimations to reduce potential biases linked to district or department-specific factors.

\subsection{Data on Industrial Activities and Economic Resources}

The economic data are coming from two surveys: the industrial survey of 1839-1847 and the agricultural survey of $1852^{15}$. The agricultural survey is used in order to control for the agricultural resources of districts. It can be held as relatively representative of the state of French agriculture in the middle of the nineteenth century (Demonet, 1990). The major issue with

\footnotetext{
${ }^{11}$ These departments are: Ardèche, Ardennes, Cher, Corrèze, Côtes-du-Nord (Côtes D'Armor), Finistère, Gard, Gers, Indre, Indre-et-Loire, Loire-Inférieure (Loire Atlantique), Loiret, Lozère, Marne, Morbihan, Nièvre, Oise, Bas-Rhin, Saone-et-Loire, Seine-et-Marne, Deux-Sèvres and Vaucluse. At that time, there were 86 departments existing and 26 academies. Current denominations of departments are specified in brackets when a change occurred.

${ }^{12}$ See for example on this point the criticisms made in (Luc, 1986) and (Luc and Gavoille, 1987). See (Grew and Harrigan, 1986) for a reply and (Furet and Sachs, 1974) for a use of these data.

${ }^{13}$ These data can be found here https://journals.openedition.org/acrh/2890

${ }^{14}$ See in Table A1 the Appendix.

${ }^{15}$ More information on them can be found in (Chanut et al., 2000) for the industrial one, in (Marin and Marraud, 2011b) and (Demonet, 1990) for the agricultural one.
} 
these data is the 20 years time-lapse that separates them from the Guizot survey. However, since agricultural characteristics were quite stable over time, they should still constitute a good approximation of the agricultural resources at the beginning of the nineteenth-century and serve as good controls for agricultural resources of districts.

Data on the location of factories as well as their characteristics are drawn from the industrial survey. These data are available at the level of municipalities, which makes it possible to match them with those on primary schools. The factories reported in the survey were composed of more than 10 workers in order not to be mingled with craftsmanship. The data coming from this survey are quite reliable. For example, the average daily wages reported are in compliance with those provided by Villermé, 1971, 1840 and comparable to those coming from other sources like the Statistique générale de la France. A comparison with the Statistique de l'industrie minérale also reinforces its reliability (Chanut et al., 2000). Data on industrial activities are therefore around ten years posterior to the ones on primary schooling. As a consequence, I have to assume that the location of factories remained stable during this time period. Unfortunately, no data at the level of municipalities prior to this date are available to support this hypothesis. However, I will focus mostly on large factories which were more likely to remain stable in their location over the ten-year gap. This will enable me to compare the presence of industrial activities to the one of primary schools with more confidence.

\subsection{Demographical Data on Municipalities}

Data on the population of municipalities is taken from the Statistique générale de la France for the year 1836. Population dispersion is taken from the Postal Survey of 1847 along with the surface area of municipalities which have disappeared or merged since $1833^{16}$. Since this survey is posterior to the Guizot one, I have to assume that population remained stable over the fourteen years separating them, which seems to be a quite reasonable assumption. The Institut national de l'information géographique et forestière, a public organism in charge of the diffusion of geographic information in France, provides surface data for the other municipalities. The altitude of municipalities is also taken from this organism.

\subsection{Descriptive Statistics}

Descriptive statistics are displayed in Table $1^{17}$. Primary schools were located in $59 \%$ of the municipalities in the data. Around $39 \%$ of them were paying teachers a fixed annual salary. Municipal salaries were however often low compared to the minimum level of 200 francs implemented by the Guizot Law, with an average level 97 francs. Generally speaking, around 47\% of the municipalities were subsidising primary schools. Industrial factories were present in $12 \%$ of the municipalities, those more than 20 workers in $6 \%$ of them. The majority of manufactures, $62.6 \%$, were less than 20 workers (1 545 factories over the 4 128). I will take this number of

\footnotetext{
${ }^{16}$ More information on this survey is available in (Marin and Marraud, 2011a).

${ }^{17}$ Descriptive statistics on agricultural controls are present in Table A2 in the Appendix.
} 
workers as a threshold and define the top third as large factories. The average population of the municipalities was around 990 inhabitants, but $50 \%$ of them were less than 631 inhabitants and 90\% less than 2 000. Population dispersion could be high within municipalities as the average scattering was around $47 \%$, with a median value close to $50 \%$.

Table 1: Summary Statistics

\begin{tabular}{|c|c|c|c|c|c|}
\hline Variable & Mean & Std. Dev. & Min. & Max. & $\mathbf{N}$ \\
\hline Primary School & 0.59 & & 0 & 1 & 8129 \\
\hline Fixed salary & 0.39 & & 0 & 1 & 8129 \\
\hline Salary amount - francs per year & 97.1 & 184.4 & 0 & 5449.5 & 8129 \\
\hline Public school & 0.47 & & 0 & 1 & 8129 \\
\hline Pupils per 100 inhabitants & 9.5 & 6.8 & 0.3 & 61.6 & 4658 \\
\hline Number of subjects & 4.6 & 1.7 & 1 & 11 & 4835 \\
\hline Schooling years & 5.3 & 1.9 & 1 & 11 & 4629 \\
\hline Percentage of population scattered & 46.8 & 35.6 & 0 & 100 & 6941 \\
\hline Population & 989.8 & 1811.9 & 30 & 75895 & 8064 \\
\hline Surface area - hectares & 1725.5 & 1439.1 & 8 & 18359 & 7844 \\
\hline Average altitude - meters & 207.7 & 194.6 & 1 & 1399 & 7844 \\
\hline Factory & 0.12 & & 0 & 1 & 8129 \\
\hline Factory more than 20 workers & 0.06 & & 0 & 1 & 8129 \\
\hline Number of factories & 0.5 & 8.5 & 0 & 699 & 8129 \\
\hline Taxes on industrial activities - francs per year & 84.6 & 1164.1 & 0 & 77445 & 8129 \\
\hline Industrial male worker daily wage - cents of francs & 210.7 & 74.3 & 40 & 500 & 930 \\
\hline Industrial female worker daily wage & 96.1 & 34.2 & 20 & 300 & 466 \\
\hline Industrial child worker daily wage & 71.8 & 30.5 & 10 & 200 & 503 \\
\hline Percentage of industrial child workers & 11 & 13.9 & 0 & 66.7 & 933 \\
\hline
\end{tabular}

Source: Guizot, agricultural, industrial and postal surveys. IGN data and Statistique générale de la France. Notes: All variables are defined at the municipal level. For example, the number of factories is equal to the average number of manufactures present in a municipality.

\section{Research Methodology}

\subsection{Econometric Model}

In this work, I focus on the beginning of the nineteenth century for three reasons. First, after 1833, the relation between industrial activities and education could be biased by the impact of the Guizot reform. Second, no data at the municipal level are available further back in time. Thirdly, since industrialisation began in the early nineteenth century in France, it would make less sense to study its interaction with primary schooling before this time period. This may 
be seen as an issue as schools might have been created before economic activities developed. However, even if it were the case, one must remember that teachers were highly dependent on fees paid by families and on the potential financial help provided by municipalities. Thus, if these municipalities were not able to support them or parents not able to pay fees, teachers could be forced to move in another area. This was entailing the disappearance of the school. In the autobiography of (Meunier, 1981), a teacher from the Eure-et-Loire department, this precariousness of teaching appears clearly, especially at the beginning of his career during which he remained an itinerant teacher. Later on, when several schools were created in the municipality in which he was settled, the battle teachers were all engaged in to attract children and benefit from fees made their activity unstable ${ }^{18}$. Therefore, at some point, a sufficient amount of wealth was needed either to create a primary school or to maintain it. The estimations will capture both effects: either the direct effect of industrial activities on the creation of schools or the indirect one on their maintaining.

As seen before, the pattern of education differed from the industrial one at the level of French departments. Therefore, there is a priori no strong reason to believe that primary schools were influencing manufactures location at the beginning of the nineteenth century. This location was more dependent on the proximity of deposits, commercial networks, canals, royal roads, ... Moreover, in the French case, early industrialisation was shown to have been more dependent on upper-tail knowledge than on the average literacy, especially for what regards the implementation of modern sectors (Squicciarini and Voigtländer, 2015) ${ }^{19}$. Therefore, even if some manufacturers may have searched for a disciplined workforce and therefore for schools (Rosanvallon, 1985), (Johnson, 1970), it is hard to imagine that this influenced greatly the location of industrial activities.

However, industrial activities and primary schools' location may have been both driven by a third factor. Resources coming from trade or agriculture for example could have prompted the creation of schools and the development of industrial production. As a consequence, the estimation of the relation between industry and schooling is subject to a potential omitted variable bias. Therefore, I will instrument industrial activities by the presence of iron, coal and copper deposits. These latter constituted the three main types of ore that were exploited at the beginning of the nineteenth century.

The second-stage estimation equation is the following:

$$
\text { School }_{m, d}=\alpha_{d}+\beta_{1} \text { Industry }_{m, d}+\beta_{2} \text { Demo }_{m, d}+\beta_{3} \text { Agr }_{\text {arr }, d}+\epsilon_{m, a r r, d}
$$

where School $_{m, d}$ is a dummy variable which equals one if a primary school was present in a given municipality $m$ within a department $d$. $\alpha_{d}$ captures time-invariant fixed effects at the

\footnotetext{
${ }^{18}$ The memoirs of Louis-Arsène Meunier were not published until 1981. He lived between 1801 and 1887.

${ }^{19}$ See also (de Pleijt and van Zanden, 2016), (Mokyr, 2005), (Baten and van Zanden, 2008) and (Allen, 2003) for a global analysis at the European level, (Mitch, 1993) for the British case. This latter estimated that, in 1841 , only $4.9 \%$ of men and $2.2 \%$ of women in England were employed in jobs where literacy was absolutely required. Around half of men were employed in jobs where it had nearly no chance of being useful.
} 
level of departments ${ }^{20}$. For example, the fact of being close to the sea or to the frontier could entail a higher wealth for municipalities trough trade activities. Industry is a dummy variable which equals one if a factory (or a large factory) was present in municipality $m$, Demo is a set of demographics and geographical variables defined at the municipal level. Agr is a set of agricultural variables defined at the level of districts. Standard errors indexed by arr are clustered at the district level. This is done in order to account for spatial correlation. Indeed, as the agricultural variables are defined at a more aggregated level than municipalities, not doing so could cause the standard errors to be seriously downward-biased and lead to spurious findings. This may happen if the micro units (the municipalities) share some unobservable characteristics in a given group (district) when the estimation is done either by OLS (Moulton, 1986), (Moulton, 1990) or using instrumental variables (Shore-Sheppard, 1996), (Hoxby and Paserman, 1998). For example, the long-term effect of Protestant settlement and the use of a patois were identified in the literature as having influenced schooling spread ${ }^{21}$.

The estimation framework of the first stage is :

$$
\text { Industry }_{m, d}=\alpha_{d}+\beta_{1} \text { Instr }_{m, d}+\beta_{2} \text { Demo }_{m, d}+\beta_{3} \text { Agr }_{a r r, d}+\epsilon_{m, d}
$$

where Inst $_{m, d}$ is a dummy variable taking the value one if a deposit was present in the municipality $m$, this deposit being exploited or not. These data are coming from the Bureau de Recherches Géologiques et Minières. The estimation will be done using a standard two-stage least squares technique. Indeed, as presented in (Angrist and Pischke, 2008) the use of a nonlinear estimation tool, as Probit or Logit, is technically off-limits in this case. There are of course also drawbacks in using least squares to estimate relations on dummies. However, since there was most of the times only one school (in $80 \%$ of the cases) and one or two factories per municipality (in $70 \%$ of the municipalities with an industry), I am forced to stick to estimations on binary indicators.

\subsection{Instrument's Validity}

As presented in (2), I use the location of coal, iron and copper deposits to instrument the presence of industrial factories. These deposits were present in 237 municipalities. Over these 237 cases, a factory was located in the same municipality in 81 cases, a large factory more than 20 workers in 56 cases. The rationale is that factories could have been present in the same municipalities as they were exploiting directly these deposits (55 cases over 81). Another reason explaining this correspondence would be that mining activities attracted other industrial factories (as clothing, food industry, ...) because, by fixing the labour-force, they were creating additional outlets for these other sectors. Then, these activities may have continued to exist,

\footnotetext{
${ }^{20}$ I will also introduce fixed effects at the district level in the estimations instead of agricultural controls and department fixed effects. Since this work is cross-sectional, I don't introduce time-varying factors at these levels.

${ }^{21}$ See for example (Laget, 1971) on the Protestant influence in the Bas-Languedoc and (Furet and Ozouf, 1977a) on the influence of the Breton patois in the Morbihan.
} 
even if the deposit was depleted and mining factories closed. It is also possible to imagine that some industries were randomly present in municipalities where deposits were located. This could be true in the case of non-exploited deposits. The main issue with the instrument used is the reduction in the source of the identifying variation. Indeed, the number of observations on industry falls greatly by using this technique. However, this should lead to the identification of a clear causal effect and prevent the analysis from being biased because of reverse causality and omitted variables. Therefore, the impact of industry should be robustly identified using this technique.

Indeed, it is hard to imagine why municipalities with ore would be richer than their counterparts, for another reason than the exploitation of the deposit by a manufacture and the potential attraction of other industrial sectors. Municipalities with deposits were as likely as the others to be located close to commercial networks for example or in districts with high agricultural resources. In the data, the average agricultural land value between districts was not varying significantly with the presence of deposits. More generally, these municipalities were unlikely to be correlated with a third factor that would have driven both schools and factories' presence. Finally, even if this point is less problematic, a potential reverse causality bias would also be avoided by this instrumental variable strategy.

There is also no strong reason to believe that deposits influenced directly the presence of schools and that the exclusion restriction would not hold. These schools were not relying on deposits for their functioning. Moreover, there is no major geographical differences between municipalities with deposits and their counterparts. The former were located at an average altitude of 250 meters against 206 for the latter, a contrast unlikely to have influenced greatly the presence of primary schools.

\section{A Positive Influence of Industrial Activities on Pri- mary Schools' Presence}

\subsection{OLS Estimations}

In Table 2, I regress the presence of primary schools on economic, demographic and geographic variables without using any instrument. Among demographical factors, population dispersion and total population's impacts remain significant with district fixed effects (columns 1 to 3 ), no fixed effects and district controls (columns 4 to 6), and department fixed effects (columns 7 to 9). A standard deviation in population dispersion was implying a fall of around 6 percentage points in the probability of primary schools' presence, a standard deviation in total population an increase of around 16 percentage point ${ }^{22}$.

The effect of industrial variables is positive and significant when district controls are introduced

\footnotetext{
${ }^{22}$ This is in line with descriptive statistics showing that schools were located in municipalities with a higher population and a lower population dispersion. See Table A3 in the Appendix.
} 
without department fixed effects ${ }^{23}$. The presence of at least one factory was increasing the probability to have at least one primary school in the same municipality by 9.5 percentage points. A one unit increase in the total number of factories was leading to a 2.2 percentage point increase of the same probability. Finally, the presence of a factory with more than 20 workers (the $37 \%$ biggest ones) was increasing this probability by 9 percentage points. Industrial activities were therefore linked to a higher spreading of primary schools. This effect was greatly due to the presence of large factories and was reinforced when several manufactures were located in the same municipality ${ }^{24}$. The association between schools and industry becomes non-significant when district or department fixed effects are introduced. Only the total number of factories remains significant at a ten or five-percent level, with a magnitude or around 1 percentage point. Therefore, the intensity of industrial factories' presence was more closely associated with primary schools.

Table 2: Industrial (large) factories and primary schools. OLS estimations

\begin{tabular}{|c|c|c|c|c|c|c|c|c|c|}
\hline & \multicolumn{9}{|c|}{ Dependent variable: Primary School } \\
\hline & $(1)$ & $(2)$ & $(3)$ & $(4)$ & $(5)$ & (6) & $(7)$ & (8) & (9) \\
\hline Industry & $\begin{array}{c}0.022 \\
(0.979)\end{array}$ & - & - & $\begin{array}{c}0.095^{* * *} \\
(3.605)\end{array}$ & - & - & $\begin{array}{c}0.013 \\
(0.605)\end{array}$ & - & - \\
\hline Number of factories & - & $\begin{array}{l}0.010^{* *} \\
(2.240)\end{array}$ & - & - & $\begin{array}{c}0.022^{* * *} \\
(4.298)\end{array}$ & - & - & $\begin{array}{l}0.008^{*} \\
(1.834)\end{array}$ & - \\
\hline Factories $>20$ workers & - & - & $\begin{array}{c}0.039 \\
(1.393)\end{array}$ & - & - & $\begin{array}{c}0.090^{* * * *} \\
(2.914)\end{array}$ & - & - & $\begin{array}{c}0.022 \\
(0.790)\end{array}$ \\
\hline Population dispersion & $\begin{array}{c}-0.043^{* * *} \\
(-4.755)\end{array}$ & $\begin{array}{c}-0.043^{* * *} \\
(-4.771)\end{array}$ & $\begin{array}{c}-0.043^{* * *} \\
(-4.759)\end{array}$ & $\begin{array}{c}-0.068^{* * *} \\
(-2.821)\end{array}$ & $\begin{array}{c}-0.068^{* * *} \\
(-2.800)\end{array}$ & $\begin{array}{c}-0.069 \text { *** } \\
(-2.821)\end{array}$ & $\begin{array}{c}-0.056^{* * *} \\
(-4.325)\end{array}$ & $\begin{array}{c}-0.056^{* * *} \\
(-4.322)\end{array}$ & $\begin{array}{c}-0.056^{* * *} \\
(-4.328)\end{array}$ \\
\hline Population & $\begin{array}{l}0.164^{* *} \\
(2.218)\end{array}$ & $\begin{array}{l}0.163^{* *} \\
(2.220)\end{array}$ & $\begin{array}{c}0.164^{* *} \\
(2.234)\end{array}$ & $\begin{array}{c}0.157^{* *} \\
(2.306)\end{array}$ & $\begin{array}{c}0.159^{* *} \\
(2.333)\end{array}$ & $\begin{array}{c}0.162^{* *} \\
(2.361)\end{array}$ & $\begin{array}{c}0.165^{* *} \\
(2.174)\end{array}$ & $\begin{array}{c}0.164^{* *} \\
(2.173)\end{array}$ & $\begin{array}{c}0.165^{* *} \\
(2.187)\end{array}$ \\
\hline Agricultural controls & Yes & Yes & Yes & Yes & Yes & Yes & Yes & Yes & Yes \\
\hline Department fixed effects & No & No & No & No & No & No & Yes & Yes & Yes \\
\hline District fixed effects & Yes & Yes & Yes & No & No & No & No & No & No \\
\hline Number of clusters & 91 & 91 & 91 & 88 & 88 & 88 & 88 & 88 & 88 \\
\hline Observations & 6723 & 6723 & 6723 & 6718 & 6718 & 6718 & 6718 & 6718 & 6718 \\
\hline$R^{2}$ & 0.448 & 0.449 & 0.449 & 0.200 & 0.199 & 0.198 & 0.345 & 0.345 & 0.345 \\
\hline
\end{tabular}

$t$ statistics in parentheses

${ }^{*} p<0.1,{ }^{* *} p<0.05,{ }^{* * *} p<0.01$

Source: Agricultural, industrial, postal and Guizot surveys. IGN data.

Notes: Primary school is an indicator variable which takes value 1 if at least a primary school was located in the municipality at stake. Industry and Factories > 20 workers are also dummy variables taking value 1 if a manufacture (more than 20 workers) was present in the given municipality. Population and population dispersion are standardised.

\footnotetext{
${ }^{23}$ Descriptively, there is a strong association between schools and factories since, in $79 \%$ of the municipalities with a factory, a school was also present. See Table A4 in the Appendix.

${ }^{24}$ Ideally, one would like to decompose the effect of manufactures on primary schooling by taking other thresholds on the number of workers. However, this would amount to restricting data too much for any econometric analysis. This is why I stick to factories more than 20 workers to measure the impact of large manufactures on primary instruction.
} 


\subsection{A Stronger Effect with IV Estimations}

In Table 3, I regress the presence of primary schools on industrial characteristics using the instrumental variable strategy presented. In all specifications, the presence of ore is significantly linked to factories in the first stage. The Sanderson-Windmeijer F-stat is superior to ten in the two last cases, which tends to exclude the issue of weak instrument. This also prevents the estimations to be greatly biased if the presence of deposits was even slightly directly correlated with the location of primary schools (Bound et al., 1995). The Regression based p-value $e^{25}$ is inferior or close to $10 \%$ which means that I can reject the exogeneity hypothesis of the Industry variable. IV estimations are therefore recommended.

Table 3: IV estimation - Industrial factories and primary schools.

\begin{tabular}{lccc}
\hline \hline & \multicolumn{3}{c}{ Dependent variable: Primary School } \\
\cline { 2 - 4 } & $(1)$ & $(2)$ & $(3)$ \\
\hline Industry & $0.393^{*}$ & $0.397^{*}$ & $0.332^{*}$ \\
& $(1.789)$ & $(1.837)$ & $(1.672)$ \\
\hline Agricultural controls & No & Yes & Yes \\
Demographic and geographic controls & Yes & Yes & Yes \\
Department fixed effects & No & No & Yes \\
District fixed effects & Yes & No & No \\
Number of clusters & 91 & 88 & 88 \\
\hline
\end{tabular}

First-stage, dependent variable is the presence of industrial activities

\begin{tabular}{lccc} 
Presence of ore & $0.149^{* * *}$ & $0.165^{* * *}$ & $0.164^{* * *}$ \\
& $(2.86)$ & $(3.74)$ & $(3.29)$ \\
Observations & & & \\
$R^{2}$ & 6723 & 6718 & 6718 \\
$F-$ stat & 0.156 & 0.051 & 0.105 \\
Regression-based p-value & 8.112 & 13.860 & 10.729 \\
\hline
\end{tabular}

$t$ statistics in parentheses

${ }^{*} p<0.1,{ }^{* *} p<0.05,{ }^{* * *} p<0.01$

Source: Agricultural, industrial, postal and Guizot surveys. IGN and BRGM data. Notes: The instrument is the presence of iron, copper and coal deposits. The dependent variable is always the location of primary schools in a given municipality.

The influence of the presence of industrial factories is always positive and significant at a tenpercent level, with a magnitude between 33 and 39 percentage points, which is much higher than the effect estimated by OLS. As $56.95 \%$ of the municipalities without industry had a primary school, if industrial factories were to be present in each of these municipalities, primary schools would be located in almost every one of them too. When interpreting the effect of factories'

\footnotetext{
${ }^{25}$ It relies on a test robust to clustering developed by Wooldridge.
} 
presence, it is interesting to look at its magnitude on the stock of primary schools. As they were located in $11.48 \%$ of the municipalities, the effect of manufactures on the stock of schools was of around $\left(11.48^{*} 35\right) 4$ percentage points. Therefore, over the $59.5 \%$ of municipalities in which at least one primary school was present, 4 percentage points of them could be explained by the presence of factories. This amounts to around 370 municipalities over the 4836 in which a school was present.

In order to specify this effect, I look at the influence of mining activities on schools. Indeed, as the instrument used is the presence of deposits, it is strongly correlated with the location of these activities. In Table 4, I use the same specification to measure this relation. A significant and positive effect is found, the presence of a mine increasing by around 30 percentage points the probability for a primary school to be found in the same municipality ${ }^{26}$. The effect of industrial activities found with the IV strategy was therefore greatly due to the mining sector, which is logical given the nature of the instrument used.

Table 4: IV estimation - Mining activities, large factories and primary schools.

\begin{tabular}{|c|c|c|c|c|c|c|}
\hline & \multicolumn{6}{|c|}{ Dependent variable: Primary School } \\
\hline & $(1)$ & $(2)$ & $(3)$ & $(4)$ & $(5)$ & $(6)$ \\
\hline \multirow[t]{2}{*}{ Mining activities } & $0.319^{*}$ & $0.342^{*}$ & $0.312^{*}$ & - & - & - \\
\hline & $(1.925)$ & $(1.858)$ & $(1.860)$ & & & \\
\hline \multirow[t]{2}{*}{ Factories $>20$ workers } & - & - & - & $0.467^{*}$ & 0.444 & $0.418^{*}$ \\
\hline & & & & $(1.727)$ & $(1.599)$ & $(1.694)$ \\
\hline Agricultural controls & No & Yes & Yes & No & Yes & Yes \\
\hline Demographic and geographic controls & Yes & Yes & Yes & Yes & Yes & Yes \\
\hline Department fixed effects & No & No & Yes & No & No & Yes \\
\hline District fixed effects & Yes & No & No & Yes & No & No \\
\hline Number of clusters & 91 & 88 & 88 & 91 & 88 & 88 \\
\hline First-stage, dependent variable is : & \multicolumn{3}{|c|}{ Mining activities } & \multicolumn{3}{|c|}{ Large factories } \\
\hline Presence of ore & $\begin{array}{c}0.184^{* * *} \\
(3.87)\end{array}$ & $\begin{array}{c}0.188^{* * *} \\
(4.04)\end{array}$ & $\begin{array}{c}0.186^{* * *} \\
(4.02)\end{array}$ & $\begin{array}{c}0.125^{* * *} \\
(3.19)\end{array}$ & $\begin{array}{c}0.144^{* * *} \\
(3.71)\end{array}$ & $\begin{array}{c}0.139^{* * *} \\
(3.49)\end{array}$ \\
\hline Observations & 6723 & 6718 & 6718 & 6723 & 6718 & 6718 \\
\hline$R^{2}$ & 0.141 & 0.108 & 0.117 & 0.100 & 0.035 & 0.060 \\
\hline$F-s t a t$ & 14.843 & 16.107 & 15.990 & 10.102 & 13.579 & 12.023 \\
\hline Regression-based p-value & 0.257 & 0.147 & 0.141 & 0.075 & 0.115 & 0.066 \\
\hline
\end{tabular}

$t$ statistics in parentheses

${ }^{*} p<0.1,{ }^{* *} p<0.05,{ }^{* * *} p<0.01$

Source: Agricultural, industrial, postal and Guizot surveys. IGN and BRGM data.

Notes: The instrument is the presence of iron, copper and coal deposits. The dependent variable is always the location of primary schools in a given municipality.

\footnotetext{
${ }^{26}$ The stock interpretation is less interesting here as mining activities were present in only $1.21 \%$ of municipalities.
} 
Moreover, this table helps to understand the high magnitude of the IV coefficients. Indeed, 11.5 factories were on average present in municipalities with mining activities against 3.6 in those with industrial activities but belonging to other sectors ${ }^{27}$. This is in line with the positive and robust effect of the total number of factories on primary schools identified in the OLS estimations. The presence of mines in these estimations is synonymous to the presence of several factories, the number of which was shown to be positively correlated to primary schools. Therefore, instrumenting the presence of factories is actually equivalent to instrumenting the presence of an average high number of manufactures. This accounts for the stronger effect found with IV estimations. Unfortunately, since the instrument used restrict highly the number of observations, I cannot include the total number of factories in the regressions. In around $70 \%$ of the municipalities with industrial activities and a deposit, only one or two factories were present. As a consequence, the first stage becomes invalid when instrumenting the number of manufacturers by the presence of deposits.

In the same table, I also report estimation coefficients of the relation between the presence of large factories with more than 20 workers, and the location of primary schools. Descriptively, there is a positive association between the two since $81.6 \%$ of the municipalities with a bigsize factory were characterised by the presence of a primary school. Even if the effect is not significant in the second specification, the presence of these factories was entailing an increase of around 42 percentage points of the primary schools' presence probability. This higher effect is coherent with what was expected since large factories were more likely to attract, be attracted by and to develop along with other activities. Indeed 319 industrial workers were on average employed in municipalities with factories more than 20 workers, with a median value of 104 workers. The income effect potentially induced by industrial production was likely to be higher when manufacturers were employing more people. Indeed, a higher production was associated with a greater amount of taxes collected by municipalities.

So far, I have shown that industrial activities were influencing positively the presence and maintaining of primary schools. The influence of geographic and demographic characteristics of municipalities was also far from being negligible. Several transmission channels can be thought of in order to explain this relation : higher expected returns from families ${ }^{28}$ and local authorities, direct investment of businessmen into schooling, a higher demand for an educated workforce where activities were dynamic, an income effect through taxes collected on the industrial production, ...

Among them, the last one seems to be the most relevant historically. Indeed, if a high demand for skills in economic activities entailing both a greater investment of businessmen into schooling and higher education returns for families existed historically, it seems that it characterised rather the second phase of the industrialisation process $^{29}$. The first phase, at the

\footnotetext{
${ }^{27}$ The difference between the two being significant at a one-percent level. This is coherent with what was found in other studies on the effect of mining activities, and especially coal, on the development of cities (Fernihough and O'Rourke, 2014).

${ }^{28}$ Even if the evaluation of these returns by families is far from obvious (Jensen, 2010).

${ }^{29}$ The greater investment of businessmen into the schooling system was also due to the will to bypass factory
} 
beginning of the nineteenth century, was linked to an accumulation of physical capital, with a low complementarity with human capital (Mitch, 1993). The increase of this complementarity in the second phase, beginning rather in the 1860s-70s in the case of France, is considered as explaining the rise in industrial wages along with the fall in rental value and inequalities (Allen, 2009), (Galor and Moav, 2006). Therefore, it seems unlikely that primary schools developed along with industrial activities following the logic of the demand for skills.

\section{A Supply-Side Effect Trough the Economic Resources of Municipalities}

From a descriptive point a view, municipalities with factories were more often paying teachers on a regular basis ( $53 \%$ of them against $37 \%$ when no industry was present), providing them more often with an accommodation (40\% against $27 \%$ ) and a classroom $(45 \% \text { against } 37 \%)^{30}$. Moreover, on average, municipalities with a school but no industry were providing teachers with a low annual fixed salary of 147 francs, compared to the minimum level of 200 francs subsequently implemented by the Guizot Law. This level was on the contrary already attained and surpassed in towns with schools and factories, with an average salary amount of 262 francs. Therefore, the provision of public schools was positively correlated to the industrial presence.

In order to investigate the causality of this effect, I regress in Table 5 the probability for a teacher to have a fixed salary, which was the most common form of public grant provided in $39 \%$ of the municipalities, on the presence of industrial factories more than 20 workers. This subsidy was the sign of a strong municipal involvement in primary instruction since, contrary to the other grants, it implied an annual contract and provision of funds from the municipality to the teacher. Consequently, a fixed salary was increasing greatly the stability of teachers' presence in a given town. This grant was therefore the most robust indicator of a strong and stable public supply of primary schools. I keep all the observations here and not only the cases of municipalities with a school. Therefore, I capture two effects at the same time. First, compared to municipalities with no schools, the influence of industrial activities on the opening of a school with a teacher paid on a regular basis. Second, compared to municipalities with schools but no regular salary, the influence of these activities on the probability to pay teachers regularly. I am forced to do so since the instrument becomes too weak when focusing only on municipalities with schools.

The effects are in compliance with what was found previously. The impact of large industrial factories presence is of around 45 percentage points. As teachers paid on a regular basis were present in $37.8 \%$ of the municipalities without large manufactures, the generalisation of industrial production would have theoretically entailed a globally shared financial capacity to pay teachers. In stock terms, as paid teachers were present in $38.92 \%$ of the municipalities,

laws aiming at regulating child work. This was especially the case in France after the passing of the 1841 law, the first one defining an upper bound on day-work hours for children depending on their age.

${ }^{30}$ See Table A5 in the Appendix. 
(45*11.48) 5.2 percentage points of them can be explained by the presence of factories. The effect estimated with OLS is positive and significant but with a much lower magnitude (around $6.5 \%$ ), as expected. The effect of the mere presence of factories was also significant in this case. I only report the influence of large factories since it was driving most of the impact on public investment in primary schooling ${ }^{31}$. Large factories were more closely linked to public education than to the mere presence of schools, especially to private ones financed only through fees. Therefore, the positive effect of industrial activities on primary schools was due to an increase in the supply of public schools. In municipalities with factories, local authorities more often invested in education by paying teachers on a regular basis. This positive influence on schooling supply went through an income effect on municipal resources.

Table 5: IV estimation - Large factories and fixed salary provision.

\begin{tabular}{|c|c|c|c|c|c|c|}
\hline & \multicolumn{6}{|c|}{ Dependent variable: Fixed salary } \\
\hline & \multicolumn{3}{|c|}{ OLS } & \multicolumn{3}{|c|}{ IV } \\
\hline & $(1)$ & $(2)$ & $(3)$ & $(4)$ & $(5)$ & $(6)$ \\
\hline Factories $>20$ workers & $\begin{array}{c}0.069^{* * *} \\
(2.768)\end{array}$ & $\begin{array}{c}0.108^{* * *} \\
(2.847)\end{array}$ & $\begin{array}{c}0.065^{* *} \\
(2.469) \\
\end{array}$ & $\begin{array}{c}0.470 * * \\
(2.070)\end{array}$ & $\begin{array}{c}0.532^{* *} \\
(1.982)\end{array}$ & $\begin{array}{c}0.444^{* *} \\
(2.022)\end{array}$ \\
\hline Agricultural controls & No & Yes & Yes & No & Yes & Yes \\
\hline Demographic and geographic controls & Yes & Yes & Yes & Yes & Yes & Yes \\
\hline Department fixed effects & No & No & Yes & No & No & Yes \\
\hline District fixed effects & Yes & No & No & Yes & No & No \\
\hline Number of clusters & 91 & 88 & 88 & 91 & 88 & 88 \\
\hline
\end{tabular}

First-stage, dependent variable is the presence of large factories

Presence of ore

$0.125^{* * *} \quad 0.145^{* * *} \quad 0.138^{* * *}$

\begin{tabular}{lcccccc} 
Observations & 6723 & 6718 & 6718 & 6723 & 6718 & 6718 \\
$R^{2}$ & 0.426 & 0.212 & 0.356 & 0.100 & 0.034 & 0.059 \\
$F-$ stat & & & & 10.102 & 13.471 & 11.914 \\
Regression-based p-value & & & & 0.066 & 0.097 & 0.070 \\
\hline \hline
\end{tabular}

$t$ statistics in parentheses

${ }^{*} p<0.1,{ }^{* *} p<0.05,{ }^{* * *} p<0.01$

Source: Agricultural, industrial, postal and Guizot surveys. IGN and BRGM data.

Notes: The instrument is the presence of iron, copper and coal deposits. The dependent variable is always the presence of a teacher paid on a regular annual basis in a given municipality.

${ }^{31}$ See Table A6 in the Appendix. 
Indeed, if these municipalities were more capable to invest in instruction, it is because industrial activities were directly contributing to municipal resources through the taxes collected on their production, the patente ${ }^{32}$. The basis of this tax was incomes coming from trade and industry. However, it is only by means of rental value that these resources were taxed. The patente amounted to a percentage between 10 and $15 \%$ of the rental value of industrial buildings. An additional component depended directly on the number of workers and engines used in the production process (Chanut et al., 2000). Therefore, municipalities collecting more taxes on industrial activities were also more likely to invest greatly in primary schooling. Descriptively, this was indeed the case as both production value and taxes on this production were higher in towns with schools, where a fixed salary or an accommodation were provided to teachers ${ }^{33}$. For example, these taxes amounted on average to 123 francs per year in municipalities paying teachers regularly against 60 francs in those which didn't. The figures for what regards accommodation were respectively 167 and 51 francs. Therefore, the municipalities investing more in education were also those whose economic resources coming from industrial activities were the highest.

The use of OLS estimations in Table 6 shows that taxes on industrial activities were linked to a higher investment in primary schooling. Indeed, municipalities with schools were more likely to pay teachers on a regular basis and to pay them more if industrial taxes collected were high $^{34}$. One standard deviation increase in the amount of taxes collected was increasing the probability to pay teachers regularly by 6 percentage points, while it increased their salary by an amount between 25 and 30 francs. This positive effect of taxes explains also why the presence of large factories was influencing highly primary schooling. Indeed, production value and taxes collected on manufactures were about ten times higher in municipalities with large factories than in municipalities with factories less than 20 workers $^{35}$. However, I find no significant effect of taxes on primary schooling using the same instrumental variable strategy used previously. The F-stat remains too low in the first stage, which makes the estimations unreliable. This is due to the limited identifying variation kept when using the mineral deposit instrument.

\footnotetext{
${ }^{32}$ One of the four direct taxes, the quatre vieilles, implemented by the Assemblée Constituante in 1791, along with the land tax, the personal property tax and the tax on doors and windows (implemented in 1798).

${ }^{33}$ See Table A7 in the Appendix.

${ }^{34}$ Taking into account all municipalities as before wouldn't change the results.

${ }^{35}$ See Table A8 in the Appendix.
} 
Table 6: Fixed salary, fixed salary amount and industrial taxes.

\begin{tabular}{|c|c|c|c|c|}
\hline & $\begin{array}{c}(1) \\
\text { Fixed salary }\end{array}$ & $\begin{array}{c}(2) \\
\text { Fixed salary }\end{array}$ & $\begin{array}{c}(3) \\
\text { Salary } \\
\text { amount }\end{array}$ & $\begin{array}{c}(4) \\
\text { Salary } \\
\text { amount }\end{array}$ \\
\hline Taxes on industrial activities & $\begin{array}{l}0.060 * * \\
(2.285) \\
\end{array}$ & $\begin{array}{c}0.063^{* * *} \\
(3.057)\end{array}$ & $\begin{array}{c}30.906^{* *} \\
(2.179)\end{array}$ & $\begin{array}{c}24.598^{* *} \\
(2.350) \\
\end{array}$ \\
\hline Agricultural controls & Yes & Yes & Yes & Yes \\
\hline Demographic and geographic controls & Yes & Yes & Yes & Yes \\
\hline Department fixed effects & No & Yes & No & Yes \\
\hline Number of clusters & 80 & 80 & 80 & 80 \\
\hline Observations & 3908 & 3908 & 3908 & 3908 \\
\hline$R^{2}$ & 0.145 & 0.272 & 0.184 & 0.351 \\
\hline
\end{tabular}

Source: Agricultural, postal and Guizot surveys. IGN data.

Notes: Only municipalities with schools are taken into account. One standard deviation in the amount of industrial taxes was linked to an increase of around $6 \%$ in the probability for teachers to have a fixed salary. The effect on the amount of this salary was between 25 and 30 francs per year.

\section{Industrial Activities, Demand for Schooling and $\mathrm{Hu}-$ man Capital}

Industrial activities influenced positively the number of schools through a positive income effect on public supply. However, this is not equivalent to a positive impact on primary schooling. Indeed, many industrial sectors relied heavily on child work. This might have entailed a negative effect of industry on the demand for schooling and human capital accumulation. In the British case for example, the study of household accounts and of a large body of biographies revealed an upsurge in child labour ${ }^{36}$ within industrial sectors during the first part of the nineteenth century (Humphries, 2012), (Humphries, 2010) ${ }^{37}$. The same kind of phenomenon was identified in the American cotton and wool industries between 1820 and 1850 (Goldin and Sokoloff, 1982). In the case of French textile industry ${ }^{38}$, the high reliance on child work was described as linked to the development of mechanisation and a more acute division of labour, contributing to make children more productive and their work complementary to the one of adults. The impoverishment of families was also associated with this phenomenon, especially in cotton

\footnotetext{
${ }^{36}$ This rise went hand in hand with a fall in the age at which children were starting to work.

${ }^{37}$ The employment of children during the Industrial Revolution has been questioned in the English case. The reliability of quantitative data and assumptions made about the work of farmers' children were central in this debate. On this point, see (Cunningham, 1990) and the replies (Kirby, 2005), (Cunningham, 2005).

${ }^{38}$ Around 145000 children under 16 years old were working in the industry according to the industrial survey, two-third of them in textile manufactures.
} 
industry, as social observers of that time already noted (Villermé, 1971, 1840) (Heywood, $1988)^{39}$.

In this section, I investigate the relation between industry and the demand for schooling by focusing on enrolment rates, on the number of subject taught within schools and on schooling years. I show that, if industry contributed positively to the supply of schools, it was negatively associated to enrolment rates and therefore to the extensive margin of human capital accumulation. The relation with its intensive margin (Were children in schools learning more when an industry was located in the same municipality ?) appears to have been only slightly positive. This part of the analysis remains descriptive since I don't find any significant effect using the IV strategy. This is actually coherent with the structure of child employment between industrial sectors. Indeed, the instrument restricts greatly the analysis to the mining sector which employed relatively few children at that time. $5.2 \%$ of its workforce was composed of children less than 16 years old according to the industrial survey while they represented $10.5 \%$ of total industrial workforce ${ }^{40}$. Moreover, seven sectors over the sixteen reported in this survey did employ more then $10.5 \%$ of children and nine more than $6 \%$. Also, the average number of children employed in manufactures was around 26 in municipalities with industrial activities other than the mining sector and 20 in municipalities with mines. Therefore, it is unlikely to find a strong impact of industrial activities on enrolment rates using the location of deposits as an instrument. Not finding any significant effect with the IV strategy and a negative association with OLS is, at least, an indication that industry didn't influence positively the demand for schooling in the first part of the nineteenth century in France.

\subsection{A Negative Association with Enrolment Rates}

Since I do not know the age structure within municipalities, enrolment is measured as the number of pupils per 100 inhabitants. To reduce the bias potentially linked to this approximation, I divide municipalities in groups depending on their population size, making the assumption that the age structure was likely to be close in each category. A first simple division consists in separating municipalities less than 2000 inhabitants (around $90 \%$ of the municipalities in the sample) from the ones above this threshold. As there are only $5 \%$ of the municipalities in the second category with more than 8000 inhabitants, each group should be quite homogeneous. Descriptively, the presence of (large) factories was related negatively to enrolment rates in small towns $^{41}$. Around 10.5 pupils were schooled during winter months in municipalities less than 2 000 inhabitants with no factories, against 8 in their counterparts. In municipalities above the

\footnotetext{
${ }^{39}$ Cotton industry was rapidly expanding at the beginning of the nineteenth century in France, especially in the Haut-Rhin department, in towns like Mulhouse or villages like Thann and Dornach and, for the department of Seine-Inférieure (named Seine-Maritime nowadays), in towns like Elbeuf. The negative effect of industrial activities on child work also seems to have been reinforced by the poor enforcement of factory laws in the time period following the one under scrutiny in this study. See for example (Saito, 2006), (Weissbach, 1977), (Pierrard, 1974) and (Pierrard, 1987) in the case of the 1841 law regulating child work in French manufactures.

${ }^{40}$ See Table A9 in the Appendix.

${ }^{41}$ See Table A10 in the Appendix.
} 
threshold, these figures were respectively of 3.6 and $4.7^{42}$. Therefore, for the vast majority of towns and villages, the presence of industrial activities was associated with lower enrolment rates.

In Table 7, I regress the number of pupils per 100 inhabitants attending schools in winter on the presence of factories ${ }^{43}$. To reduce biases linked to age structure and migration flows, I divide estimations by population bounds, estimating the effects on municipalities less than 2 000 inhabitants and on those more than 631, which is the median population level. I don't report the coefficients on municipalities below this level as the effect is close to the one on those less than 2000 inhabitants. This reinforces the idea that municipalities below this threshold were quite homogeneous. The effect found is negative, reducing the number of pupils per 100 inhabitants by around 0.7 for the towns below 2000 inhabitants and by 0.8 for the towns above median population. However, only the association in smaller towns remains significant after the introduction of department fixed effects, with a magnitude of around 0.5. This corresponds to an average reduction of $5 \%$ in enrolment rate. Taking the presence of large factories or the industrial production as explanatory factors wouldn't change the results.

A greater reliance on child work in smaller villages where families had on average lower economic resources might explain this association. An alternative explanation would be that the presence of more dynamic industrial activities prompted children to enter the workforce simply because they were (perceived as) linked to better career perspectives than primary schooling. Even if there was no legal lower bound on the age of child workers before 1841, these assumptions were likely to be true for children between 9 or 10 and 15 years old. Indeed, younger children were rarely employed within factories. There was also no clear age bounds on enrolment in primary schools. Primary instruction was typically concerning pupils between 4 and 15 years old, with a potentially high variation in the starting age, in the number of schooling years (5 years on average) and in the regularity of the attendance. Therefore, child work might have affected a significant part of the children who could possibly attend primary schools.

\footnotetext{
${ }^{42}$ These differences are significant at a one-percent level for both t-tests depending on the presence of factories or large factories. The variation in enrolment rate levels between big and small municipalities can be explained by the age structure of the population and by the migration of young workers towards bigger towns.

${ }^{43}$ Taking winter enrolment makes more sense than taking summer enrolment. Indeed, as many pupils had to assist adults in agricultural tasks, they attended school only between October and April months.
} 
Table 7: Industrial factories and enrolment.

\begin{tabular}{|c|c|c|c|c|}
\hline & \multicolumn{4}{|c|}{ Dependent variable: Pupils per 100 inhabitants } \\
\hline & (1) & $(2)$ & $(3)$ & $(4)$ \\
\hline \multirow[t]{2}{*}{ Industry } & $-0.728^{* *}$ & $-0.525^{*}$ & $-0.756^{* *}$ & -0.246 \\
\hline & $(-2.414)$ & $(-1.881)$ & $(-2.595)$ & $(-0.911)$ \\
\hline Population & $<2000$ & $<2000$ & $\geq 631$ (Median) & $\geq 631$ \\
\hline Agricultural controls & Yes & Yes & Yes & Yes \\
\hline Demographic and geographic controls & Yes & Yes & Yes & Yes \\
\hline Department fixed effects & No & Yes & No & Yes \\
\hline District fixed effects & No & No & No & No \\
\hline Number of clusters & 79 & 79 & 80 & 80 \\
\hline Observations & 3550 & 3550 & 1930 & 1930 \\
\hline$R^{2}$ & 0.490 & 0.589 & 0.481 & 0.658 \\
\hline
\end{tabular}

Source: Agricultural, industrial, postal and Guizot surveys. IGN data.

Notes: Only municipalities with primary schools are taken into account. The effect of the presence of a manufacture in a given municipality was a reduction in the number of pupils per 100 inhabitants of around 0.7 when no department fixed effects are introduced.

\subsection{More Children in Factories, Lower Enrolment}

The negative association between industry and enrolment rates was indeed coming from child work (Pierrard, 1987), (Cunningham and Viazzo, 1996). The employment of children was common in the early nineteenth-century France. In the 1820 s for example, one-third of the industrial workforce in Alsace was less than 16 years old. Some sectors, as the furniture, textile, luxury, ceramics, building, science and metal objects ones had a workforce composed of more than $10 \%$ of children ${ }^{44}$. The geographical distribution of textile factories, one of the leading sectors at that time as it accounted for one-third of total industrial product, was closely related to the one of child workers (see Figure 2). It was this sector which contributed the most to the employment of children at the national level in absolute terms. Food, chemistry, lightning and leather sectors were, on the contrary, employing a very little share of children (less than $4 \%$ of their workforce). Using this data, I split sectors into two groups: a first one in which more than $10 \%$ of the workforce was composed of children and a second one in which children were representing less than $10 \%$ of total industrial workers. This amounts to selecting the seven sectors employing more children over the sixteen reported in the industrial data.

I estimate their relation with enrolment in Table 8. These sectors were associated with a fall in enrolment rates of around $1.7 \%$ for the whole sample and $1 \%$ in municipalities less than 2000

\footnotetext{
${ }^{44}$ See Table A9 in the Appendix to have a decomposition by the 16 sectors reported in the industrial survey. These percentages are computed for France and are not restricted to the 22 departments in my database.
} 
inhabitants or less than median population. This effect was of $0.85 \%$ in towns more than this median level. I also find a negative effect of textile, building and ceramics sectors, which were among the ones employing children more intensively ${ }^{45}$. The magnitude of the effect is close for textile and building sectors, diminishing enrolment rates by more than 1.7 children per 100 inhabitants.

Table 8: Child-work intensive industrial sectors and enrolment. OLS estimations

\begin{tabular}{|c|c|c|c|c|c|c|c|}
\hline & \multicolumn{7}{|c|}{ Dependent variable: Pupils per 100 inhabitants } \\
\hline & $(1)$ & $(2)$ & $(3)$ & $(4)$ & $(5)$ & $(6)$ & $(7)$ \\
\hline Sectors $>10 \%$ & $-1.681^{* * *}$ & $-0.922^{* * *}$ & $-1.240^{* * *}$ & $-0.854^{* * *}$ & - & - & - \\
\hline child workers & $(-4.636)$ & $(-2.834)$ & $(-2.787)$ & $(-2.833)$ & & & \\
\hline Textile & - & - & - & - & $\begin{array}{c}-1.747^{* * *} \\
(-3.375)\end{array}$ & - & - \\
\hline Building & - & - & - & - & - & $\begin{array}{c}-1.991^{* * *} \\
(-4.715)\end{array}$ & - \\
\hline Ceramics & - & - & - & - & - & - & $\begin{array}{l}-1.354^{*} \\
(-1.973)\end{array}$ \\
\hline Population & All & $\leq 631$ (Median) & $<2000$ & $\geq 631$ & All & All & All \\
\hline Agricultural controls & Yes & Yes & Yes & Yes & Yes & Yes & Yes \\
\hline Demographic and geographic controls & Yes & Yes & Yes & Yes & Yes & Yes & Yes \\
\hline Department fixed effects & Yes & No & No & No & Yes & Yes & Yes \\
\hline District fixed effects & No & No & No & No & No & No & No \\
\hline Number of clusters & 80 & 66 & 79 & 80 & 80 & 80 & 80 \\
\hline Observations & 3814 & 3550 & 1886 & 1930 & 3814 & 3814 & 3814 \\
\hline$R^{2}$ & 0.479 & 0.490 & 0.395 & 0.481 & 0.579 & 0.578 & 0.577 \\
\hline
\end{tabular}

$t$ statistics in parentheses

${ }^{*} p<0.1,{ }^{* *} p<0.05,{ }^{* * *} p<0.01$

Source: Agricultural, industrial, postal and Guizot surveys. IGN data.

Notes: In these estimations, all dependent variables are dummies which equal 1 if industrial activities were located in a given municipality. The effect of the sectors in which the average percentage of child workers among industrial workers was superior to ten at the national level is measured, both gathering them into a dummy variable or taking them separately. This corresponded to furniture, textile, luxury, ceramics, building, science-letters and arts and metal objects sectors. The presence of these sectors was related to a fall in enrolment of around 1.7 children per 100 inhabitants when all observations are taken into account.

Manufacturers often resorted to child work because of its complementarity with adults' one, its low cost, the higher docility of children and, sometimes, to avoid innovation (Cunningham, 2000). The Marxist tradition argued that the use of children was meant to decrease the wage of adult workers and ensure higher profits. Descriptively, there was a negative association between child work and the average wage of male adults. In the building and textile sectors, daily industrial male wages were far below the average national level of 1.98 francs, namely 1.78 and 1.82 francs respectively ${ }^{46}$. Regressing the presence of sectors using child work intensively (more than $10 \%$ of the workforce) and the location of textile factories on daily industrial male wages, I also find that child employment was linked to lower male wages. The effect was negative

\footnotetext{
${ }^{45}$ As the effects are about the same magnitude when taking into account towns with more than 2000 inhabitants or population above or below the median, I only report the general case. Textile factories were located in 308 municipalities in the data, building manufactures in 157 and ceramics one in 48.

${ }^{46}$ See Table A11 in the Appendix to have the average industrial wages by sector.
} 
and significant, with a magnitude of around 15 cents of francs for both ${ }^{47}$. Sectors employing more children relative to the total number of workers were therefore also those paying less their male workers in the sample. It is hard to know if the effect followed the Marxist theory or if families more often sent their children to work when wages were low. In any case, the greater reliance on child work was linked to the precariousness of families.

\subsection{Human Capital Accumulation}

Industrial activities were therefore associated to lower enrolment rates and had no positive impact on the extensive margin of the demand for schooling. In Table 9, I investigate their effect on its intensive margin by regressing industrial variables on the number of subjects taught and the average length of education in primary schools ${ }^{48}$. The number of subjects was varying between one and eleven. These were: religious instruction, reading, writing, spelling, grammar, arithmetic, land surveying, linear drawing, geography, history and music. The most common subjects were religious instruction, reading and writing which were taught in nearly all the schools ${ }^{49}$. The average schooling years were also reported between one and eleven. The education of pupils was typically beginning at five years old and was rarely extended over fifteen years old in the primary institution. Since education was thought in a more linear way than nowadays, one subject being taught after the other, learning more was equivalent to attending school for a longer number of years.

There was a positive and significant association between industrial production, the presence of large factories and the number of subjects taught. However, no significant relation with the number of schooling years appears in the estimations. It is not possible to know the proportion of pupils that was learning a given number of subjects in each schools thanks to the Guizot survey, but this constitutes an indication that, if indeed more subjects were taught in municipalities with factories, only a very restricted amount of pupils were actually learning all of them. Indeed, if the majority of pupils were so, this should have increase the average schooling length as they were staying at school for a longer period of time. These results indicate that some pupils were learning more, however too few to change the time spent on average by children at school.

Ultimately, industry had at best a restricted positive effect on the intensive margin of human capital accumulation. Not finding any significant impact with the IV strategy also gives strength to this idea. Indeed, I find no indication that this increase was actually due to the very presence of factories and not to the general well-being of a given municipality, caused by high trade or agricultural resources. Moreover, I find no impact in the OLS estimations of the mere presence of factories on the number of subjects. This makes the interpretation of the

\footnotetext{
${ }^{47}$ See Table A12 in the Appendix.

${ }^{48}$ In $80.4 \%$ of the cases, there was only one school in the municipality. When several schools were present, I took the average value of schooling years and number of subjects taught between them.

${ }^{49}$ They were so in respectively $99.4,98.4$ and $92.1 \%$ of the primary schools for which this information is available. Arithmetic was taught in $62 \%$ of the schools, grammar in $44 \%$, spelling in $49 \%$, geography and linear drawing in $7 \%$, land surveying in $10 \%$, history and music in around $3 \%$.
} 
positive association with large factories and the industrial production as an industry-specific effect even more doubtful. This is coherent with the work of Diebolt et al., 2017a. They found that industry was influencing positively the supply of primary schools in the first part of the nineteenth century, while, in the second part, its influence on human capital became significant for what regards intermediate skills, proxied by adult education and enrolment in superior primary schools. In its initial phase, and at least until the mid-nineteenth century (Diebolt et al., 2017b), industrialisation (and the food and textile leading sectors) were certainly not enough skill-demanding to influence greatly and significantly the demand either for basic or for intermediary education. This is why I only find a positive but very restricted relation with the accumulation of skills beyond the mere mastering of literacy.

Table 9: Industrial activities and human capital accumulation.

\begin{tabular}{|c|c|c|c|c|c|c|c|c|}
\hline & \multicolumn{4}{|c|}{ Number of subjects } & \multicolumn{4}{|c|}{ Schooling years } \\
\hline & $(1)$ & $(2)$ & $(3)$ & $(4)$ & $(5)$ & $(6)$ & $(7)$ & $(8)$ \\
\hline \multirow[t]{2}{*}{ Taxes on industrial activities } & $0.231^{* *}$ & $0.196^{* *}$ & - & - & 0.004 & -0.100 & - & - \\
\hline & $(2.069)$ & $(2.231)$ & & & $(0.032)$ & $(-1.116)$ & & \\
\hline \multirow{2}{*}{ Factories $>20$ workers } & - & - & $0.374^{* * *}$ & $0.333^{* * *}$ & - & - & 0.084 & -0.025 \\
\hline & & & $(2.965)$ & $(2.690)$ & & & $(0.583)$ & $(-0.229)$ \\
\hline Agricultural controls & Yes & Yes & Yes & Yes & Yes & Yes & Yes & Yes \\
\hline Demographic and geographic controls & Yes & Yes & Yes & Yes & Yes & Yes & Yes & Yes \\
\hline Department fixed effects & No & Yes & No & Yes & No & Yes & No & Yes \\
\hline District fixed effects & No & No & No & No & No & No & No & No \\
\hline Number of clusters & 80 & 80 & 80 & 80 & 79 & 79 & 79 & 79 \\
\hline Observations & 3907 & 3907 & 3907 & 3907 & 3750 & 3750 & 3750 & 3750 \\
\hline$R^{2}$ & 0.086 & 0.148 & 0.087 & 0.149 & 0.402 & 0.577 & 0.402 & 0.576 \\
\hline \multicolumn{9}{|l|}{$t$ statistics in parentheses } \\
\hline \multicolumn{9}{|l|}{${ }^{*} p<0.1,{ }^{* *} p<0.05,{ }^{* * *} p<0.01$} \\
\hline Source: Agricultural, industrial, postal and C & ot surve & IGN $\mathrm{c}$ & & & & & & \\
\hline
\end{tabular}

\section{Conclusion}

The impact of industrialisation on primary schooling in the early nineteenth-century France may seem to have been odd at first sight. Indeed, the presence of factories contributed to increase the supply of public primary schools through a positive income effect, having at the same time no positive impact on the demand for schooling. There was, on the contrary, a negative association between industry and enrolment rates, due to the prevalence of child work in some sectors like textile. It is even more doubtful to argue that industrial activities caused an increase in the intensive margin of human capital accumulation.

Therefore, one could legitimately wonder why municipalities bothered to invest in education if the demand was the same, while the additional resources coming from industrial production 
could be used to build or maintain roads for example. In fact, several reasons can be thought of to answer this question. First, local authorities may have wanted to favour the education of the few pupils that were learning from private tutors or, more informally, any altruistic educated adult. Municipalities might also have opened schools thinking that it would be an efficient mean to prevent children from working at an early age. The data on enrolment rates tend to indicate that this was in fact not efficient. All along the nineteenth century, industry put a high pressure on primary schooling through the employment of children. Even the laws aiming at regulating child work in factories and pits (in 1841 notably and 1874 to a lesser extent) were easily bypassed by manufacturers, either by conjuring up the negative effects on profits or by creating schools directly within the factories. The laws on compulsory education, the Ferry Laws of 1881-1882 in France, had a stronger effect and dealt a fatal blow to child work. Finally, the imitation of bigger towns may also have played a role in favour of the spread of primary schools.

Therefore, the asymmetrical impact of industrialisation on primary schooling came from the fact that it had an indirect positive income effect on the supply of schools, while it had no or a direct negative effect on enrolment rates and the demand for schooling. This last point deserves a deeper investigation in the French case, especially given the intensive use of children in some industrial sectors. As said before, the absence of effect using the IV strategy is certainly due to the restriction in terms of observations and sectors generated by the use of the mineral deposit instrument. The use of OLS is at least an indication that industry didn't contribute to increase enrolment rates. However, because of reverse causality and omitted variables issues, it doesn't constitute an evaluation of the causal impact of industry on enrolment. Finally, I don't claim in this work that industry never had a positive impact on the demand for skills. However, I find no indication of this phenomenon in the first part of the nineteenth century in France. 


\section{References}

E. Allain. L'instruction primaire en France avant la Révolution. Tardieu, 1881.

R.C Allen. Progress and poverty in early modern Europe. The Economic History Review, 56 (3):403-443, 2003.

R.C Allen. Engels' pause : technical change, capital accumulation, and inequality in the British industrial revolution. Explorations in Economic History, 46(4):418-435, 2009.

J.D. Angrist and J.S. Pischke. Mostly Harmless Econometrics: An Empiricist's Companion. Princeton University Press, 2008.

J-C. Asselain. Histoire économique de la France du XVIIIe siècle à nos jours. 1. De l'Ancien Régime à la Première Guerre Mondiale. Editions du Seuil, 1984.

J. Baten and J.L. van Zanden. Book production and the onset of modern economic growth. Journal of Economic Growth, 13(3):217-235, 2008.

J. Bound, D.A Jaeger, and R.M. Baker. Problems with instrumental variables estimation when the correlation between the instruments and the endogeneous explanatory variable is weak. Journal of the American Statistical Association, 90(430):443-450, 1995.

J-M. Chanut, J. Heffer, J. Mairesse, and G. Postel-Vinay. L'Industrie française au milieu du 19e siècle: les enquêtes de la statistique générale de la France. Recherches d'histoire et de sciences sociales. Editions de l'Ecole des hautes études en sciences sociales, 2000.

A. Corbin. Pour une étude sociologique de la croissance de l'alphabétisation au XIXe siècle : l'instruction des conscrits du Cher et de l'Eure-et-Loir (1833-1883). Revue d'histoire économique et sociale, 53(1):99-120, 1975.

F. Crouzet. Essai de construction d'un indice annuel de la production industrielle française au XIXe siècle. Annales. Economies, Sociétés, Civilisations., 25e année(1):56-99, 1970.

H. Cunningham. The Employment and Unemployment of Children in England c. 1680-1851. Past \& Present, 126:115-150, 1990.

H. Cunningham. The decline of child labour : labour markets and family economics in Europe and North America since 1830. Economic History Review, 53(3):409-428, 2000.

H. Cunningham. How Many Children Were "Unemployed in Eighteenth- and NineteenthCentury England ? Reply. Past \& Present, 187:203-215, 2005.

H. Cunningham and P.P. Viazzo. Child labour in historical perspective - 1800-1895 - Case studies from Europe, Japan and Colombia. Number 3. Historical Perspectives. International Child Development Centre, Florence, 1996. 
D'Angeville. Essai sur le statistique de la population française considérée sous quelques-uns de ses rapports physiques et moraux. Bourg, 1836.

A.M. de Pleijt. Human capital formation in the long run: evidence from average years of schooling in England, 1300-1900. Cliometrica, 12:99-126, 2018.

A.M. de Pleijt and J.L. van Zanden. Accounting for the "Little Divergence: what drove economic growth in pre-industrial Europe, 1300-1800? European Review of Economic History, 20:387-409, 2016.

A.M. de Pleijt and J.L Weisdorf. Human capital formation from occupations: The "deskilling hypothesis" revisited. CGEH Working Paper Series, (57), 2014.

A.M. de Pleijt, A. Nuvolari, and J. Weisdorf. Human Capital Formation during the First Industrial Revolution: Evidence from the Use of Steam Engines. Comparative Advantage in the Global Economy (CAGE) Working Paper, 294, 2016.

M. Demonet. Tableau de l'agriculture française au milieu du 19e siècle : l'enquête de 1852. Ecoles des Hautes Etudes en Sciences Sociales, Paris, 1990.

C. Diebolt, C. Le Chapelain, and A-R. Menard. Industrialization as a Deskilling Process? Steam Engines and Human Capital in XIXth Century France. Working Papers of BETA, 17, $2017 \mathrm{a}$.

C. Diebolt, A-R. Menard, and F. Perrin. Behind the fertility-education nexus: what triggered the French development process? European Review of Economic History, 21:357-392, 2017b.

A.L Dunham. La révolution industrielle en France (1815-1848). Librairie Marcel Rivière et Cie, 1953.

C. Dupin. Effets de l'enseignement populaire de la lecture, de l'écriture et de l'arithmétique, de la géométrie et de la mécanique appliquée aux arts, sur la prospérité de la France. Paris, 1826.

G. Duveau. Les instituteurs. Le temps qui court. Éditions du Seuil, 1957.

N.E. Feldman and K. van der Beek. Skill choice ans skill complementarity in eighteenth century England. Explorations in Economic History, 59, 2015.

A. Fernihough and K.H. O'Rourke. Coal and the European Industrial Revolution. NBER Working Paper, 19802, 2014.

M. Fleury and P. Valmary. Les progrès de l'instruction élémentaire de louis XIV à Napoléon III, d'après l'enquête de Louis Maggiolo (1877-1879). Population, 1:71-92, 1957.

R. Franck and O. Galor. Technology-skill complementarity in the early phase of industrialization. NBER Working Paper, 23197, 2017. 
F. Furet and J. Ozouf. Lire et écrire, l'alphabétisation des Français de Calvin à Jules Ferry I. Les Editions de Minuit, 1977a.

F. Furet and J. Ozouf. Lire et écrire, l'alphabétisation des Français de Calvin à Jules Ferry II. Les Editions de Minuit, 1977b.

F. Furet and W. Sachs. La croissance de l'alphabétisation en France. Annales. Economies, Sociétés, Civilisations., 29e année(3):714-737, 1974.

O. Galor and O. Moav. Das human-kapital : a theory of the demise of the class structure. Review of Economic Studies, 73:85-117, 2006.

O. Galor, O. Moav, and D. Vollrath. Inequality in land ownership, the emergence of human capital promoting institutions, and the Great Divergence. Review of Economic Studies, 73 (1):143-179, 2009.

R. Gildea. Education in Provincial France, 1800-1914: A Study of Three Departments. Clarendon Press, 1983.

C. Goldin and L.F Katz. Why United States led in education : lessons from secondary school expansion, 1910 to 1940. NBER Working Paper, (6144), 1997.

C. Goldin and K. Sokoloff. Women, children and industrialization in the Early Republic : evidence from the manufacturing censuses. The Journal of Economic History, 42(4), 1982.

M. Gontard. L'enseignement primaire en France: de la Révolution à la loi Guizot (1789-1833). Annales de l'Université de Lyon: Lettres. Les Belles Lettres, 1959.

R. Grew and P.J Harrigan. L'offuscation pédantesque. observations sur les préoccupations de J.N Luc. Annales. Economies, Sociétés, Civilisations., 41e année(4):913-922, 1986.

R. Grew and P.J Harrigan. School, State, and Society: The Growth of Elementary Schooling in Nineteenth-century France : a Quantitative Analysis. University of Michigan Press, 1991.

F. Guizot. Rapport au Roi par le minsistre d'Etat au département de l'Instruction publique, sur l'exécution de la loi du 28 juin 1833, relative à l'instruction primaire. Paris, De l'Imprimerie Royale, 1834.

C. Heywood. Childhood in nineteenth-century France. Work, health and education among the classes populaires. Cambridge University Press, 1988.

C. Hoxby and M. Paserman. Overidentification tests with grouped data. NBER Working Paper 223, 1998.

J. Humphries. Childhood and Child Labour in the British Industrial Revolution. Cambridge Studies in Economic History - Second Series. Cambridge University Press, 2010. 
J. Humphries. Childhood and child labour in the British industrial revolution. Economic History Review, 66(2):395-418, 2012.

R. Jensen. The (perceived) returns to education and the demand for schooling. The Quarterly Journal of Economics, 125(2):515-548, 2010.

R. Johnson. Educational policy and social control in early Victorian England. Past E Present, 49:96-119, 1970.

D. Julia. L'enseignement primaire dans le diocèse de Reims à la fin de l'Ancien Régime. Annales historiques de la Révolution française, 42e année(200):233-286, 1970.

O. Katz. The Effect of Industrialization on Fertility and Human Capital in the 19th Century: Evidence from the United States. Working Paper, 2016.

H. Kellenbenz. Industries rurales en occident de la fin du Moyen Age au XVIIIe siècle. Annales. Economies, Sociétés, Civilisations., 18e année(5):833-882, 1963.

P. Kirby. How Many Children Were "Unemployed in Eighteenth- and Nineteenth-Century England? Past \& Present, 187:187-202, 2005.

M. Laget. Petites écoles en languedoc au XVIIIe siècle. Annales. Economies, Sociétés, Civilisations., 26e année(6):1398-1418, 1971.

T.W. Laqueur. Literacy and social mobility in the Industrial Revolution in England. Past and Present, 64(1):96-107, 1974.

M. Leblond. La scolarisation dans le département du Nord au XIXe siècle. Revue du Nord, 52 (206):387-398, 1970.

P. Léon. Deux siècles d'activité minière et métallurgique en Dauphiné : l'usine d'Allevard (1675-1870). Revue de géographie alpine, tome 36(2):215-258, 1948.

B. Lepetit. Sur les dénivellations de l'espace économique en France, dans les années 1830. Annales. Economies, Sociétés, Civilisations., 41e année(6):1243-1272, 1986.

P. Lorain. Tableau de l'instruction primaire. Paris, 1837.

J-N. Luc. L'illusion statistique. Annales. Économies, Sociétés, Civilisations., 4:887-911, 1986.

J-N. Luc and J. Gavoille. Faut-il brûler la statistique de l'enseignement primaire ? Histoire de l'éducation, 33:47-64, 1987.

M. Lévy-Leboyer. Les processus d'industrialisation : le cas de l'Angleterre et de la France. Revue Historique, T.239(Fasc.2), 1968.

B. Marin and M. Marraud. L'enquête postale de 1848. L'Atelier du Centre de recherches historiques, 2011a. URL http://acrh.revues.org/3707; DOI : 10.4000/acrh. 3707. 
B. Marin and M. Marraud. L'enquête agricole de 1852. L'Atelier du Centre de recherches historiques, 2011b. URL http://acrh.revues.org/3696;DOI:10.4000/acrh.3696.

F. Mayeur. Hitoire de l'enseignement et de l'éducation III. 1789-1930. Editions Perrin, 2004.

F. Mendels. Proto-Industrialization : the first phase of the Industrialization process. The Journal of Economic History, 32(1):241-261, 1972.

L-A. Meunier. Mémoires d'un ancêtre ou les tribulations d'un instituteur percheron. Cahiers percherons, 1er et 2è trimestre(65-66), 1981.

D. Mitch. The role of human capital in the first industrial revolution. In J. Mokyr, editor, The British industrial revolution: an economic perspective, pages 267-307. 1993.

J. Mokyr. The intellectual origins of modern economic growth. The Journal of Economic History, 65(2):285-351, 2005.

J. Mokyr. The British Industrial Revolution: An Economic Perspective. Boulder, 2008.

B. Moulton. Random group effects and the precision of regression estimates. Journal of Econometrics, 32:385-397, 1986.

B. Moulton. An illustration of a pitfall in estimating the effects of aggregate variables on micro units. The Review of Economics and Statistics, 72(2), 1990.

S.J Nicholas and J.M Nicholas. Male Literacy, "Deskilling" and the Industrial Revolution. The Journal of Interdisciplinary History, 23(1), 1992.

C. Nique. Comment l'Ecole devint une affaire d'Etat. Editions Nathan, 1990.

P. Pierrard. L'enseignement primaire à Lille sous la Monarchie de Juillet. Revue du Nord, 56 (220):1-11, 1974.

P. Pierrard. Enfants et jeunes ouvriers en France (XIXe - XXe siècle). Les éditions ouvrières. Paris, 1987.

A. Prost. Histoire de l'enseignement en France: 1800-196\%. Collection V. Série Histoire Contemporaine. Colin, 1968.

G. Richard. La Grande Metallurgie en Haute-Normandie à la fin du XVIIIe siècle. Annales de Normandie, 12e année(4), 1962.

M. Roncayolo. Population agglomérée, villes et bourgs en France : réflexions sur les enquêtes de 1809-1811. Villes et territoire pendant la période napoléonienne (France et Italie). Actes du colloque de Rome (3-5 mai 1984) Rome : École Française de Rome, pages 201-220, 1987.

P. Rosanvallon. Le moment Guizot. Paris, Editions Gallimard, 1985. 
Y. Saito. Le problème du travail des enfants en Alsace au XIXe siècle : l'industriel alsacien et la loi du 22 mars 1841. Histoire, économie et société, 25e année - Historiographies japonaise et sud-coréenne(2):181-193, 2006.

M. Sanderson. Literacy and social mobility in the Industrial Revolution in England. Past and Present, 56(1):75-104, 1972.

B. Sandre and M. Ozouf. La Classe ininterrompue: cahiers de la famille Sandre, enseignants 1780-1960. Hachette littérature. Hachette, 1979.

P. Savoie. Les caractères originaux de l'histoire de l'Etat enseignant français, XIXe-XXe siècles. Histoire de l'éducation, 140-141, 2014.

R.S. Schofield. Dimensions of illiteracy, 1750-1850. Explorations in Economic History, 10, issue 4:437-454, 1973.

H. Sée. L'évolution commerciale et industrielle de la France sous l'Ancien Régime. Paris. Marcel Giard, 1925.

L. Shore-Sheppard. The precision of instrumental variables estimates with grouped data. Working Paper 374. Princeton University, Industrial Relations Section, 1996.

M. Squicciarini and N. Voigtländer. Human capital and industrialization: Evidence from the age of enlightenment. Quarterly Journal of Economics, 30(4):1825-1883, 2015.

M. Suteau. La politique scolaire de la ville de Nantes, de 1830 à 1870. Histoire de l'éducation, L'offre locale d'enseignement. Les formations techniques et intermédiaires. XIXe-XXe siècles (66):85-108, 1995.

R. Thabault. Mon village: ses hommes, ses routes, son école. Références. Presses de la Fondation Nationale des Sciences Politiques, 1993.

P. Verley. La Révolution industrielle. Editions Gallimard, 1997.

P. Verley. La première révolution industrielle. Armand Colin, Paris, 1999.

R. L. Villermé. Tableau de l'état physique et moral des ouvriers employés dans les manufactures de coton, de laine et de soie. 10/18, 1971, 1840.

M. Vovelle. Y a-t-il eu une révolution culturelle au XVIIIe siècle ? A propos de l'éducation populaire en Provence. Revue d'histoire moderne et contemporaine, 22(1):89-141, 1975.

L.S Weissbach. Child labor legislation in nineteenth-century France. The Journal of Economic History, 37(1):268-271, 1977.

E.G West. Literacy and the Industrial Revolution. Economic History Review, 31(3), 1978. 


\section{Appendix for on-line publication}

\section{Data and descriptive statistics}
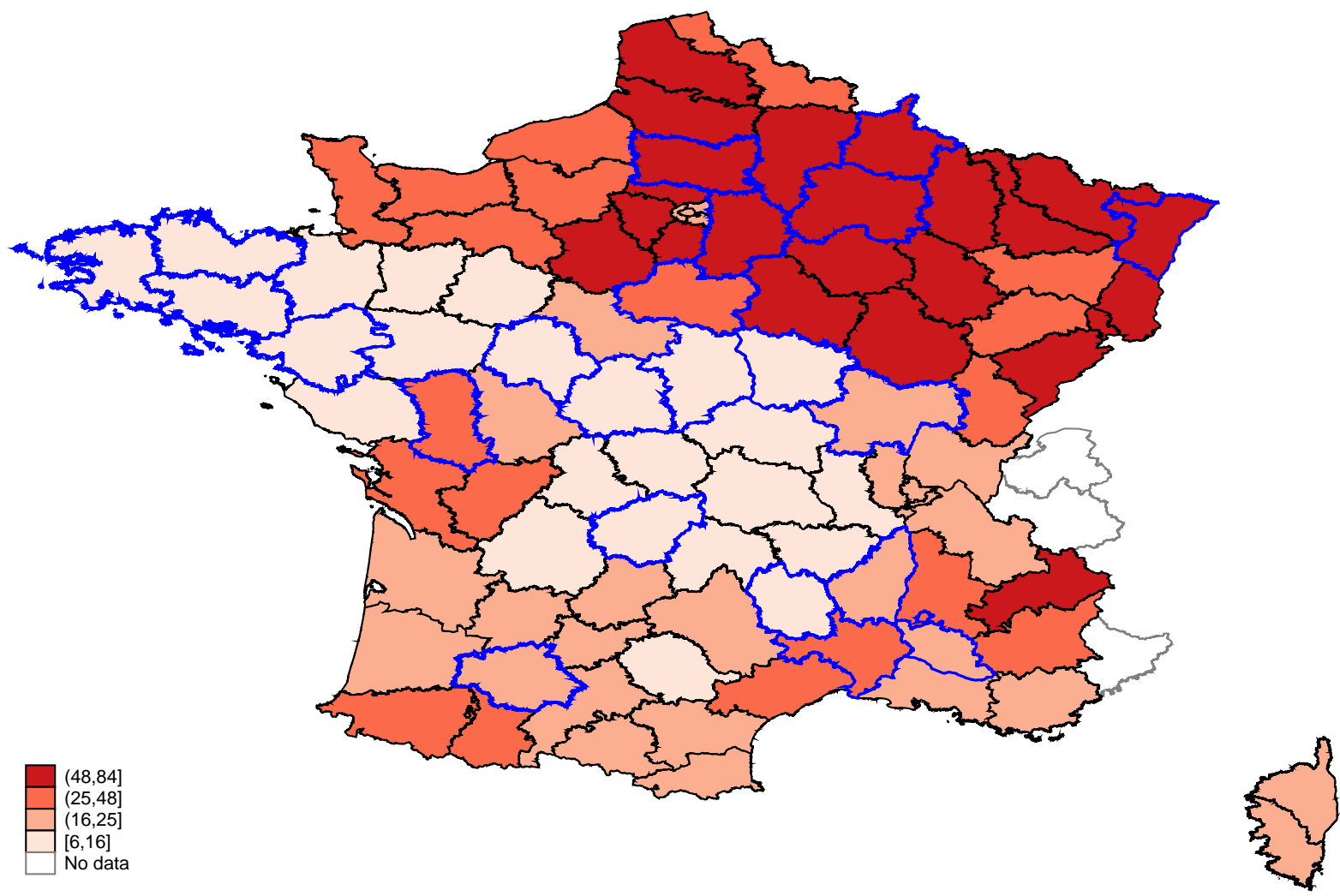

Figure B1: Percentage of children from 5 to 13 years old going to school - winter 1833

Source: Guizot survey - Report to the King, 1851 Census.

Notes: I use here the 1851 Census to take into account the age structure of the population. I consider the proportion of 5 to 13 years old children in the 1851 population and apply it to the 1833 one in order to have the total number of children that could potentially go to school at that time. Therefore, I assume that the major part of the population of children attending primary schools should be contained within these bounds. Then, I compute the percentage of children 5 to 13 years old going to school in 1833 using this measure. Departments in blue are the ones for which education data are available at the level of municipalities. 
Table A1: Data representativeness, means and t-tests

\begin{tabular}{lccc}
\hline & France & Municipal level sample & t-test \\
\hline Population & 91948 & 85794 & NS \\
Number of municipalities & 105 & 90 & $* * *$ \\
Percentage of population scattered & 49.4 & 55.4 & $*$ \\
Average altitude - meters & 300 & 211 & $* * *$ \\
Surface area - hectares & 1566 & 1869 & $* * *$ \\
& & & \\
Percentage of municipalities with schools & 71.5 & 60.8 & $* * *$ \\
Primary schools per 100 municipalities & 215 & 79 & NS \\
Teachers with a fixed salary per 100 municipalities & 48.1 & 51.9 & NS \\
Teachers with an accommodation per 100 municipalities & 43.6 & 46.8 & NS \\
Pupils per 100 children and single people & 19.9 & 16.5 & $* *$ \\
& & & \\
Percentage of municipalities with factories & 17.2 & 21.6 & $* *$ \\
Percentage of municipalities with factories $>20$ workers & 7.6 & 8.3 & NS \\
Number of industrial workers & 3592 & 2531 & NS \\
Industrial male worker daily wage - cents of francs & 192 & 187 & NS \\
Taxes on industrial activities - francs per year & 12733 & 12591 & NS \\
\hline
\end{tabular}

*** $\mathrm{p}<0.01,{ }^{* *} \mathrm{p}<0.05,{ }^{*} \mathrm{p}<0.1$.

Source: Guizot, industrial and postal surveys. IGN data and Statistique générale de la France.

Notes: All figures are computed at the level of districts. The average population in each district was respectively around 85794 inhabitants for those belonging to the municipality level sample and around 91948 inhabitants for the entire France. The difference between the two is non-significant.

Table A2: Summary Statistics - Agricultural controls

\begin{tabular}{lccccc}
\hline \hline \multicolumn{1}{c}{ Variable } & Mean & Std. Dev. & Min. & Max. & N \\
\hline Day-workers per 100 self-employed & 111.6 & 73.7 & 19.1 & 481.2 & 90 \\
Share-croppers per 100 self-employed & 10.7 & 17.7 & 0 & 103 & 90 \\
Tenant farmers per 100 self-employed & 27.7 & 43.9 & 0.3 & 294.8 & 90 \\
Average land area per self-employed - hectares & 17.1 & 11.6 & 3.8 & 74.3 & 90 \\
Total agricultural area - hectares & 150635 & 46431.5 & 49732 & 265577 & 90 \\
Land value by hectare - francs & 1645.9 & 607.8 & 625.7 & 3925.7 & 90 \\
Food \% in day-workers family spendings & 66.5 & 3.9 & 59.1 & 79.2 & 90 \\
Animals per inhabitant & 2 & 1.1 & 0.4 & 5 & 90 \\
\hline
\end{tabular}

Source: Agricultural survey.

Notes: All variables are defined at the districts level. For example the land value by hectare is the average market price of agricultural land between districts. 


\section{Description of data}

\section{Guizot Survey}

School is an indicator variable taking value one if at least one primary school was present in the municipality of reference.

Fixed salary is an indicator variable taking value one if at least one teacher was paid on an annual fixed basis in the municipality at stake. The salary amount was reported in francs per year.

Accommodation is an indicator variable taking value one if at least one teacher was provided with an accommodation or an accommodation allowance by the municipality.

\section{Industrial Survey}

Industry is an indicator variable referring to the presence of at least one industrial factory in a given municipality. An industrial factory was reported only if it exceeded ten workers in order not to be mingled with craftsmanship.

Factory $>\mathbf{2 0}$ workers is an indicator variable taking value one it at least one industrial factory with more than 20 workers was located in the municipality under scrutiny.

Industrial production value and taxes : they are both defined annually and in francs. Taxes on production were called the patente and were based on the rental value of manufactures.

Industrial wages : daily wages of male, female and child industrial workers in cents of francs.

\section{Bureau de Recherches Géologiques et Minières}

Location of deposits : copper, iron and coal. Deposits exploited and not-exploited.

\section{Agricultural Survey}

In this survey, all the data are available at the district level.

Number of tenant farmers and share-croppers : both were employed by a landowner to work on his fields and were paying him in return. The different is that share-croppers' payment was in kind (a part of harvests) while tenant farmers paid landowners directly in cash.

Number of day-workers : following (Demonet, 1990), taken as the sum of "aides agricoles" (agricultural assistant) in the survey. They amounted to 3.7 millions over all French territory.

Number of self-employed : are gathered in this category all the agricultural workers that could live from their work in the fields, that is to say all the people that owned land and worked on it directly plus those that owned land and made other people work on it. Landowners who 
worked on their land but also on someone else's property were not counted. This measure is more restricted as the one made in (Demonet, 1990) who also included farmers and sharecroppers in this category.

Land value : measured as the mean, in franc per hectare, of four land values considered relevant to describe agricultural land. Namely, ploughable land, vineyards, pastures and forests. In the original data, these lands were decomposed in three quality classes whose repartition in the total land is unknown. Each value is taken as an average value over these three classes.

Agricultural area : in hectares, taking the same four types of land that are used to measure land value.

Food percentage in day-workers spendings : for a day-worker family of five members, food spendings (bread, vegetables, meat, milk, wine, cider, beer and salt) as a percentage of all spendings (food plus accommodation, clothing, heating, taxes and diverse spendings).

Number of animals : taken as the sum of wool animals (rams, sheep, ewes, lambs), pigs, billy goats, goats, young goats and horn animals (bulls, ox, cows, bull-calves, steers, heifers). Horses are excluded from this category as they were mainly bred in the wealthy north-est part of France.

\section{Geographical data from the Institut Géographique National}

Average altitude : in meters.

Surface area of municipalities : in hectares.

\section{Postal Survey}

Population dispersion : taken as the share of the total population that didn't match the contiguity criterion. See (Roncayolo, 1987) on this point.

Total population : taken from this survey if missing in the Guizot Survey.

\section{Statistique générale de la France}

Number of children : 5-15 years old children, taken from the 1851 French Census.

Literacy 1686-1690 : evaluated as the marriage signature rate for men. 
Table A3: Primary schools, demographic and geographic characteristics, means and t-tests

\begin{tabular}{lccc}
\hline & No primary school & Primary school & t-test \\
\hline Population & 731 & 1167 & $* * *$ \\
Average altitude & 226.7 & 195.1 & $* * *$ \\
Surface area & 1725.6 & 1725.5 & NS \\
Population scattered $(\%)$ & 58.9 & 37.8 & $* * *$ \\
\hline$* * * \mathrm{p}<0.01,{ }^{* *} \mathrm{p}<0.05,{ }^{*} \mathrm{p}<0.1$. & & &
\end{tabular}

Source: Guizot and postal surveys, IGN data.

Notes: The average population of municipalities with no primary school was 731 inhabitants. There were on average 1167 inhabitants in towns where at least one primary school is present. The difference is significant at a one-percent level.

Table A4: Presence of factories and primary schools

\begin{tabular}{|c|c|c|c|}
\hline & No industry & Industry & Total \\
\hline \multirow[t]{3}{*}{ No primary school } & 3098 & 195 & 3293 \\
\hline & 43.1 & 20.9 & 40.5 \\
\hline & 94.1 & 5.9 & 100.0 \\
\hline \multirow[t]{3}{*}{ Primary school } & 4098 & 738 & 4836 \\
\hline & 56.9 & 79.1 & 59.5 \\
\hline & 84.7 & 15.3 & 100.0 \\
\hline \multirow[t]{3}{*}{ Total } & 7196 & 933 & 8129 \\
\hline & 100.0 & 100.0 & 100.0 \\
\hline & 88.5 & 11.5 & 100.0 \\
\hline Observations & 8129 & & \\
\hline \multicolumn{4}{|c|}{ Pearson $\operatorname{chi} 2(12)=168.1641 \mathrm{Pr}=0.000$} \\
\hline \multicolumn{4}{|c|}{ Source: Guizot and industrial surveys. } \\
\hline \multicolumn{4}{|c|}{$\begin{array}{l}\text { Notes: There were } 3098 \text { cases of municipalities with no pri- } \\
\text { mary school and no factory. } 43.1 \% \text { of the municipalities with }\end{array}$} \\
\hline
\end{tabular}




\section{Income effect}

Table A5: Industrial factories and investment in primary education, means and t-tests

\begin{tabular}{lccc}
\hline & No industry & Industry & t-test \\
\hline Fixed salary (percentage of municipalities) & 37 & 53 & $* * *$ \\
Fixed salary amount (in francs per year) & 83.5 & 201.9 & $* * *$ \\
Accommodation (percentage of municipalities) & 27 & 40 & $* * *$ \\
Accommodation allowance (in francs per year) & 5.2 & 11.5 & $* * *$ \\
Classroom (percentage of municipalities) & 31 & 45.2 & $* * *$
\end{tabular}

Taking into account only the municipalities with schools

\begin{tabular}{lccc} 
Fixed salary amount (in francs per year) & 146.6 & 262.3 & $* * *$ \\
Accommodation allowance (in francs per year) & 9.1 & 14.9 & $* * *$ \\
\hline${ }^{* * *} \mathrm{p}<0.01,{ }^{* *} \mathrm{p}<0.05,{ }^{*} \mathrm{p}<0.1$. & &
\end{tabular}

Source: Guizot and industrial surveys.

Notes: In $37 \%$ of the municipalities with no industry, a teacher was granted with a fixed salary. The average fixed salary was of 83.5 francs per year in municipalities with no industry. This average salary was of 146.6 francs when the sample is restricted to municipalities with a school. 
Table A6: IV estimation - Industrial factories and fixed salary.

\begin{tabular}{lccc}
\hline \hline & \multicolumn{3}{c}{ Dependent variable : Fixed salary } \\
\cline { 2 - 4 } & & & \\
& $(1)$ & $(2)$ & $(3)$ \\
\hline Industry & $0.395^{*}$ & $0.453^{*}$ & $0.390^{*}$ \\
& $(1.924)$ & $(1.860)$ & $(1.959)$ \\
\hline Agricultural controls & No & Yes & Yes \\
Demographic and geographic controls & Yes & Yes & Yes \\
Department fixed effects & No & No & Yes \\
District fixed effects & Yes & No & No \\
Number of clusters & 91 & 88 & 88 \\
\hline
\end{tabular}

First-stage, dependent variable is the presence of industrial activities

\begin{tabular}{lccc} 
Presence of ore & $0.149^{* * *}$ & $0.165^{* * *}$ & $0.164^{* * *}$ \\
& $(2.86)$ & $(3.74)$ & $(3.29)$ \\
& & & \\
Observations & 6723 & 6718 & 6718 \\
$R^{2}$ & 0.156 & 0.051 & 0.105 \\
$F-$ stat & 8.112 & 13.860 & 10.729 \\
Regression-based p-value & 0.053 & 0.067 & 0.041 \\
\hline \hline
\end{tabular}

$t$ statistics in parentheses

${ }^{*} p<0.1,{ }^{* *} p<0.05,{ }^{* * *} p<0.01$

Source: Agricultural, industrial, postal and Guizot surveys. IGN and BRGM data. Notes: The instrument is the presence of iron, copper and coal deposits. The dependent variable is always the presence of a teacher paid on a regular annual basis in a given municipality. 
Table A7: Industrial production, taxes and primary schooling, means and t-tests

\begin{tabular}{lccc}
\hline & No primary school & Primary school & t-test \\
\hline Taxes on industrial activities (in francs per year) & 21.2 & 114.1 & $* * *$ \\
Industrial production value (in francs per year) & 11069.3 & 97535 & $* * *$ \\
& & & \\
& No fixed salary & Fixed salary & t-test \\
Taxes on industrial activities & 60 & 123.2 & $* *$ \\
Industrial production value & 44675.3 & 113658.3 & $* * *$ \\
& & & \\
Taxes on industrial activities & No accommodation & Accommodation & t-test \\
Industrial production value & 51.4 & 167.4 & $* * *$ \\
\hline
\end{tabular}

$* * * \mathrm{p}<0.01,{ }^{* *} \mathrm{p}<0.05,{ }^{*} \mathrm{p}<0.1$.

Source: Guizot and industrial surveys.

Notes: In the municipalities in which no primary school was present, taxes on industrial activities amounted on average to 21.2 francs per year. This low figure is explained by the fact that in many municipalities, no manufacture was present. These cases are counted as zero value in the computation of the average taxes. Focusing on municipalities with industrial activities would lead to higher figures. The average level in municipalities with a primary school amounted to 114 francs. The difference is significant at a one-percent level.

Table A8: Industrial production, taxes and large factories, means t-tests

\begin{tabular}{lccc}
\hline & $\begin{array}{c}\text { Industry } \\
<20 \text { workers }\end{array}$ & $\begin{array}{c}\text { Industry } \\
>20 \text { workers }\end{array}$ & t-test \\
\hline Taxes on industrial activities (in francs per year) & 125.8 & 1179.4 & $* * *$ \\
Industrial production value (in francs per year) & 94186 & 1006482 & $* * *$ \\
\hline$* * * \mathrm{p}<0.01,{ }^{* *} \mathrm{p}<0.05,{ }^{*} \mathrm{p}<0.1$. & & &
\end{tabular}

Source: Industrial survey.

Notes: In municipalities with factories less than 20 workers, taxes on industrial activities amounted to 125.8 francs per year on average. In towns with manufactures more than 20 workers, they amounted to 1179.4 francs on average. The difference between the two is significant at a onepercent level. 


\section{Industrial activities and the demand for schooling}

Table A9: Industrial sectors and percentage of children among workers

\begin{tabular}{lcccc}
\hline & Mean & Standard Deviation & Minimum & Maximum \\
\hline Furniture & 25.7 & 17.7 & 0 & 50 \\
Textile & 17.9 & 16.1 & 0 & 100 \\
Luxury & 13.8 & 20.1 & 0 & 66.7 \\
Ceramics & 11.3 & 12.6 & 0 & 66.7 \\
Building & 11.2 & 15.3 & 0 & 75 \\
Science, letters and arts & 11.2 & 14.9 & 0 & 75 \\
Metal Objects & 10.5 & 13.5 & 0 & 100 \\
Metallurgy & 6.4 & 9.7 & 0 & 58.6 \\
Transports & 6.3 & 10.7 & 0 & 50 \\
Clothing & 5.3 & 12.5 & 0 & 90 \\
Mining activities & 5.2 & 10.4 & 0 & 66.7 \\
Wood & 5 & 11.3 & 0 & 48.5 \\
Leather & 3.8 & 10.4 & 0 & 100 \\
Lightning & 3.5 & 10.6 & 0 & 66.7 \\
Chemistry & 3.4 & 9.9 & 0 & 76.9 \\
Food & 3 & 8 & 0 & 100 \\
& & & & \\
All sectors & 10.5 & 14.6 & 0 & 100 \\
\hline
\end{tabular}

Source: Industrial survey.

Notes: The average percentage of child workers among industrial workers at the national level in textile factories was 17.9 , with a standard deviation of 16.1. The minimum percentage in this sector was zero, the maximum one hundred. Sectors are reported in decreasing order with respect to the mean. 
Table A10: Industrial factories and enrolment, means and t-tests

\begin{tabular}{lccc}
\hline & No industry & Industry & t-test \\
\hline Pupils per 100 inhabitants - Winter & 9.9 & 6.9 & $* * *$ \\
Pupils per 100 inhabitants - Summer & 4 & 3.6 & $* * *$ \\
Pupils per 100 inhabitants (mean) & 6.6 & 5 & $* * *$ \\
& & & \\
Pupils per 100 inhabitants - Winter, $<2000$ inhabitants & 10.5 & 8.2 & $* * *$ \\
Pupils per 100 inhabitants - Summer, $<2000$ inhabitants & 4.4 & 3.8 & $* * *$ \\
& & & \\
Pupils per 100 inhabitants - Winter, $>2000$ inhabitants & 3.6 & 4.7 & $* * *$ \\
Pupils per 100 inhabitants - Summer, $>2000$ inhabitants & 2.1 & 3.2 & $* * *$ \\
& & & \\
\hline & No industry & Industry & t-test \\
& $>20$ workers & $>20$ workers & \\
\hline Pupils per 100 inhabitants - Winter & 9.7 & 7 & $* * *$ \\
Pupils per 100 inhabitants - Summer & 4.1 & 3.6 & $* *$ \\
Pupils per 100 inhabitants (mean) & 6.5 & 5.1 & $* * *$ \\
Pupils per 100 inhabitants - Winter, $<2000$ inhabitants & 10.4 & 8.4 & $* * *$ \\
Pupils per 100 inhabitants - Summer, $<2000$ inhabitants & 4.4 & 3.8 & $* *$ \\
Pupils per 100 inhabitants - Winter, $>2000$ inhabitants & 3.8 & 4.9 & $* * *$ \\
Pupils per 100 inhabitants - Summer, $>2000$ inhabitants & 2.4 & 3.3 & $* * *$ \\
\hline$* * *$ p $<0.01, * *$ p $<0.05, *$ p $<0.1$. & & &
\end{tabular}

Source: Guizot and industrial surveys.

Notes: In municipalities with no industrial factories, 9.9 children per 100 inhabitants were enrolled in primary schools in wintertime. 6.9 children were so in municipalities with industry at the same period. The difference is statistically significant at a one-percent level. Only municipalities with at least one primary school are taken into account. 
Table A11: Industrial sectors and industrial male workers' wage

\begin{tabular}{lcccc}
\hline & Mean & Standard Deviation & Minimum & Maximum \\
\hline Luxury & 260 & 84 & 110 & 475 \\
Transports & 254 & 75 & 130 & 425 \\
Metallurgy & 244 & 82 & 100 & 625 \\
Metal Objects & 233 & 93 & 75 & 660 \\
Science, letters and arts & 222 & 79 & 90 & 550 \\
Furniture & 220 & 63 & 125 & 335 \\
Chemistry & 215 & 62 & 75 & 450 \\
Ceramics & 213 & 76 & 85 & 500 \\
Lightning & 210 & 74 & 100 & 400 \\
Wood & 203 & 72 & 75 & 500 \\
Mining activities & 202 & 72 & 75 & 500 \\
Food & 198 & 66 & 50 & 550 \\
Leather & 195 & 51 & 75 & 650 \\
Clothing & 190 & 68 & 25 & 450 \\
Building & 182 & 54 & 75 & 450 \\
Textile & 178 & 64 & 25 & 600 \\
All sectors & & & & \\
\hline
\end{tabular}

Source: Industrial survey.

Notes: The average wage of industrial male workers was 260 cents of francs in the luxury sector at the national level, with a standard deviation of 84 cents. The minimum wage reported was 110 cents in this sector and the maximum 475 cents. Sectors are reported in decreasing order with respect to the average wage. 
Table A12: Child-work intensive industrial sectors and industrial wages.

\begin{tabular}{|c|c|c|c|c|c|}
\hline & \multicolumn{5}{|c|}{ Dependent variable : Daily industrial male wage } \\
\hline & $(1)$ & $(2)$ & (3) & $(4)$ & (5) \\
\hline Sectors $>10 \%$ & $-17.647^{*}$ & $-15.224^{*}$ & $-12.917^{*}$ & - & - \\
\hline child workers & $(-1.936)$ & $(-1.898)$ & $(-1.853)$ & & \\
\hline \multirow[t]{2}{*}{ Textile } & - & - & - & $-16.241^{*}$ & - \\
\hline & & & & $(-1.742)$ & \\
\hline \multirow[t]{2}{*}{ Building } & - & - & - & - & -16.311 \\
\hline & & & & & $(-1.567)$ \\
\hline Agricultural controls & No & Yes & Yes & Yes & Yes \\
\hline Demographic and geographic controls & Yes & Yes & Yes & Yes & Yes \\
\hline Department fixed effects & No & No & Yes & Yes & Yes \\
\hline District fixed effects & Yes & No & No & No & No \\
\hline Number of clusters & 81 & 80 & 80 & 80 & 80 \\
\hline Observations & 614 & 613 & 613 & 613 & 613 \\
\hline$R^{2}$ & 0.446 & 0.192 & 0.335 & 0.338 & 0.335 \\
\hline
\end{tabular}

$t$ statistics in parentheses

${ }^{*} p<0.1,{ }^{* *} p<0.05,{ }^{* * *} p<0.01$

Source: Agricultural, industrial, postal and Guizot surveys. IGN data.

Notes: In these estimations, all dependent variables are dummies which equal 1 if industrial activities were located in a given municipality. The effect of the sectors in which the average percentage of child workers was superior to ten at the national level is measured, both gathering them into a dummy variable or taking them separately. This corresponded to furniture, textile, luxury, ceramics, building, science-letters and arts and metal objects sectors. The presence of these sectors was related to a fall in industrial male worker daily wage of around 15 cents of francs. 